\title{
Chain length-dependent cooperativity in fatty acid binding and oxidation by cytochrome $\mathrm{P}^{4} 0_{\mathrm{BM} 3}$ (CYP102A1)
}

\author{
Benjamin Rowlatt, Jake A. Yorke, Anthony J. Strong, Christopher J. C. Whitehouse, Stephen G. Bell, \\ Luet-Lok Wong ${ }^{\square}$
}

Department of Chemistry, University of Oxford, Inorganic Chemistry Laboratory, South Parks Road, Oxford OX1 3QR, UK

\ Correspondence: luet.wong@chem.ox.ac.uk

Received July 21, 2011 Accepted August 2, 2011

\section{ABSTRACT}

Fatty acid binding and oxidation kinetics for wild type $\mathrm{P}^{450} \mathrm{BM}_{3}$ (CYP102A1) from Bacillus megaterium have been found to display chain length-dependent homotropic behavior. Laurate and 13-methyl-myristate display Michaelis-Menten behavior while there are slight deviations with myristate at low ionic strengths. Palmitate shows Michaelis-Menten kinetics and hyperbolic binding behavior in $100 \mathrm{mmol} / \mathrm{L}$ phosphate, $\mathrm{pH}$ 7.4, but sigmoidal kinetics (with an apparent intercept) in low ionic strength buffers and at physiological phosphate concentrations. In low ionic strength buffers both the heme domain and the full-length enzyme show complex palmitate binding behavior that indicates a minimum of four fatty acid binding sites, with high cooperativity for the binding of the fourth palmitate molecule, and the full-length enzyme showing tighter palmitate binding than the heme domain. The first flavin-to-heme electron transfer is faster for laurate, myristate and palmitate in $100 \mathrm{mmol} / \mathrm{L}$ phosphate than in $50 \mathrm{mmol} / \mathrm{L}$ Tris (pH 7.4), yet each substrate induces similar high-spin heme content. For palmitate in low phosphate buffer concentrations, the rate constant of the first electron transfer is much larger than $k_{\text {cat }}$. The results suggest that phosphate has a specific effect in promoting the first electron transfer step, and that $\mathrm{P}^{450_{\mathrm{BM} 3}}$ could modulate Bacillus membrane morphology and fluidity via palmitate oxidation in response to the external phosphate concentration.

KEYWORDS P450 $0_{\mathrm{BM} 3}$, monooxygenase, fatty acid, cooperativity, allosteric effect, CYP102A1

\section{INTRODUCTION}

The cytochrome P450 superfamily (http://drnelson.uthsc.edu/ CytochromeP450.html) of heme monooxygenases is found in organisms in all kingdoms of life, with over 11,000 CYP genes in genome databases. P450 enzymes catalyze the oxidation of a wide range of organic compounds by atmospheric oxygen. Of special importance is the oxidation of $\mathrm{C}-\mathrm{H}$ bonds to the alcohol functionality, but other reaction types such as epoxidation, dealkylation and desaturation are also known (Guengerich, 2001). P450 enzymes are involved in the biosynthesis of steroids, vitamins, antibiotics, eicosanoids, and plant secondary metabolites which are a rich source of biologically active compounds, e.g. the anti-malarial artemisinin. The CYP1, CYP2 and CYP3 families of human P450 enzymes metabolize $>80 \%$ of clinical drugs. The $\mathrm{C}-\mathrm{H}$ bond activation activity of $\mathrm{P} 450$ s also has potential applications in biotechnology (Urlacher and Eiben, 2006; Bell et al., 2007).

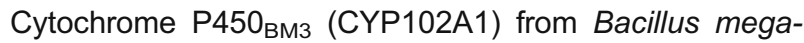
terium is a sub-terminal medium-chain fatty acid hydroxylase (Narhi and Fulco, 1986). Its physiological substrate has not been established. P450 $_{\text {Вм3 }}$ consists of a diflavin (FAD-FMN) electron-transfer reductase domain, similar to eukaryotic $\mathrm{P} 450$ s, fused to the C-terminus of a heme monooxygenase domain in a single $119 \mathrm{kDa}$ polypeptide. It exhibits some of the highest substrate oxidation activity of all P450 enzymes (Narhi and Fulco, 1987), and has been extensively engineered for the oxidation of non-natural substrates to target specific products such as fine chemicals and drug metabolites (Bell et al., 2007).

Of the 29 currently known members of the CYP102 family, 15 are in the A subfamily and the remaining 14 in subfamilies 
B-J. All but the four B-subfamily enzymes are fused polypeptides similar to CYP102A1. Of the A-subfamily enzymes only CYP102A1, A2, A3, A5 and A7 have been studied in detail. The $\mathrm{A} 2$ and $\mathrm{A} 3$ enzymes show a preference for branched-chain over linear-chain fatty acids (Budde et al., 2004; Gustafsson et al., 2004; Lentz et al., 2004), A5 prefers polyunsaturated fatty acids over their saturated counterparts (Chowdhary et al., 2007), while A7 is broadly similar to the A1 enzyme (Dietrich et al., 2008). The substrate binding and turnover kinetics of both $\mathrm{A} 2$ and $\mathrm{A} 3$ show sigmoidal behavior, indicating the binding of more than one substrate molecule and possible cooperativity. No sigmoidal behavior has been reported for fatty acid binding or oxidation by $\mathrm{P} 450_{\mathrm{BM} 3}$ (Gustafsson et al., 2004), though isotope effect studies suggested that both laurate and palmitate could be simultaneously present in the active site (Rock et al., 2003). On the other hand, both homotropic and heterotropic cooperativity have been reported for the oxidation of non-natural substrates

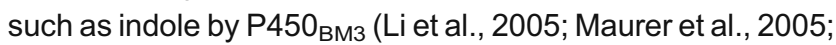
Huang et al., 2007), and for drug metabolism by the R47L/ F87V/L188Q mutant in which allosteric effects were also proposed (van Vugt-Lussenburg et al., 2006).

The functional form of $\mathrm{P}_{450_{\mathrm{BM}}}$ is a dimer. Monooxygenase activity is negligible in the monomeric form of the enzyme (Neeli et al., 2005; Kitazume et al., 2007; Girvan et al., 2011). Electrons are supplied by NADPH to one monomer and subsequently transferred to the other monomer. Detailed understanding of the properties and function of $\mathrm{P}^{4} 50_{\mathrm{BM} 3}$ is further complicated by the fact that enzyme activity is strongly dependent on buffer composition and ionic strength (Kitazume et al., 2007). The heme spin state of the $N$ palmitoylglycine-bound enzyme varies significantly with temperature (Jovanovic et al., 2005). We noticed that the heme spin state of the palmitate-bound enzyme showed more pronounced temperature variability in $100 \mathrm{mmol} / \mathrm{L}$ phosphate than in $50 \mathrm{mmol} / \mathrm{L}$ Tris (unpublished results). This led us to examine the effect of buffer and ionic strength on the binding, steady state oxidation kinetics and first flavin-to-heme electron transfer for $\mathrm{P} 450_{\mathrm{BM} 3}$ with lauric (dodecanoic), myristic (tetradecanoic) and palmitic (hexadecanoic) acid as substrate. The results of these studies are reported in this paper.

\section{RESULTS}

\section{The heme spin state of fatty acid-bound $\mathrm{P} 450_{\mathrm{BM}}$ varies with ionic strength}

All data reported in this work were obtained at $\mathrm{pH} 7.4$ and $30^{\circ} \mathrm{C}$. Fatty acid binding to $\mathrm{P}^{4} 50_{\mathrm{BM}}$ induced the well known type I spectral shift. Laurate binding induced a shift of the heme spin state from fully low spin (LS) in the substrate-free form to $40 \%$ high spin (HS) in $50 \mathrm{mmol} / \mathrm{L}$ Tris (Table 1). Myristate and palmitate binding induced $65 \%$ and $95 \% \mathrm{HS}$ heme content, respectively. The laurate-induced spin state shift was slightly larger in $100 \mathrm{mmol} / \mathrm{L}$ phosphate than in $50 \mathrm{mmol} / \mathrm{L}$ Tris (45\% vs $40 \%$ ), but myristate and palmitate gave similar shifts in both buffers.

Addition of $400 \mathrm{mmol} / \mathrm{L}$ Tris, phosphate or $\mathrm{KCl}$ to lauratebound $\mathrm{P} 450_{\mathrm{BM} 3}$ in $50 \mathrm{mmol} / \mathrm{L}$ Tris shifted the heme to $65 \%$ $\mathrm{HS}$, and to $80 \%$ for the myristate-bound form (Table 1). Interestingly, palmitate binding in $10 \mathrm{mmol} / \mathrm{L}$ phosphate induced a shift to only $55 \%$ HS heme, but this increased to $70 \%$ in $25 \mathrm{mmol} / \mathrm{L}$ and $95 \%$ in $50 \mathrm{mmol} / \mathrm{L}$ phosphate. The heme spin state of palmitate-bound $\mathrm{P} 450_{\mathrm{BM}}$ is therefore considerably more sensitive at low ionic strength.

\section{The first flavin-to-heme electron transfer is dependent on buffer but not ionic strength}

The rate constant for the formation of the Fe"-CO species via heme reduction followed by rapid $\mathrm{CO}$ binding, $k_{\mathrm{f}}$, is an acceptable indicator of $k_{\text {et }}$, the rate constant for the first flavinto-heme electron transfer. $k_{\mathrm{f}}$ was $(1.5 \pm 0.3) \mathrm{s}^{-1}$ in $50 \mathrm{mmol} / \mathrm{L}$ Tris or $100 \mathrm{mmol} / \mathrm{L}$ phosphate in the absence of substrate (Whitehouse et al., 2010), but significantly higher for the fatty acid-bound forms. In $50 \mathrm{mmol} / \mathrm{L}$ Tris, $k_{\mathrm{f}}$ was $(58 \pm 7.6) \mathrm{s}^{-1}$ for laurate, $(102 \pm 7.0) \mathrm{s}^{-1}$ for myristate, and $(227 \pm 15) \mathrm{s}^{-1}$ for palmitate (Fig. 1 and Table 2). The corresponding values in $100 \mathrm{mmol} / \mathrm{L}$ phosphate were $(107 \pm 21) \mathrm{s}^{-1},(233 \pm 23) \mathrm{s}^{-1}$ and $(303 \pm 24) \mathrm{s}^{-1}$, respectively. Increasing the buffer strength from 50 to $250 \mathrm{mmol} / \mathrm{L}$ Tris or from 100 to $300 \mathrm{mmol} / \mathrm{L}$ phosphate did not have a statistically significant effect on $k_{\mathrm{f}}$ for laurate or palmitate (Table 2). $k_{\mathrm{f}}$ remained high at $(305 \pm$ 17) $\mathrm{s}^{-1}$ in $25 \mathrm{mmol} / \mathrm{L}$ phosphate and dropped only as far as

Table 1 Percentage of high spin heme content (estimated to within $5 \%$ ) of fatty acid-bound full-length $\mathrm{P} 450_{\mathrm{BM}}$ at $30^{\circ} \mathrm{C}$, $\mathrm{pH} 7.4$, in different buffers and salt concentrations

\begin{tabular}{lccccccccccccc}
\hline & $50 \mathrm{mmol} / \mathrm{L}$ & \multicolumn{4}{c}{ With added Tris $(\mathrm{mmol} / \mathrm{L})$} & \multicolumn{3}{c}{ With added phosphate $(\mathrm{mmol} / \mathrm{L})$} & \multicolumn{4}{c}{ With added $\mathrm{KCl}(\mathrm{mmol} / \mathrm{L})$} \\
& Tris & 100 & 200 & 300 & 400 & 100 & 200 & 300 & 400 & 100 & 200 & 300 & 400 \\
\hline Laurate & 40 & 45 & 50 & 60 & 65 & 45 & 55 & 60 & 65 & 45 & 50 & 60 & 65 \\
Myristate & 65 & 70 & 75 & 80 & 80 & 65 & 70 & 75 & 80 & 65 & 70 & 75 & 75 \\
Palmitate & 95 & 95 & 95 & 95 & 95 & 95 & 95 & 95 & 95 & 95 & 95 & 95 & 95 \\
\hline
\end{tabular}


A

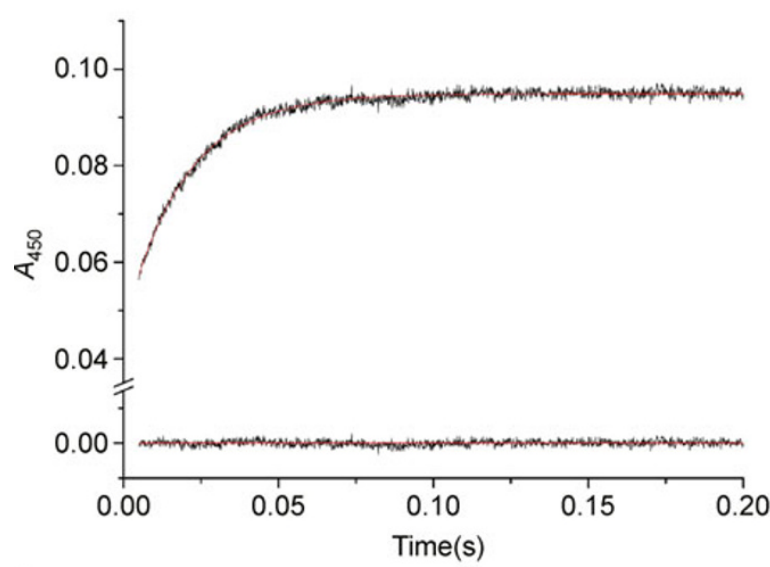

C

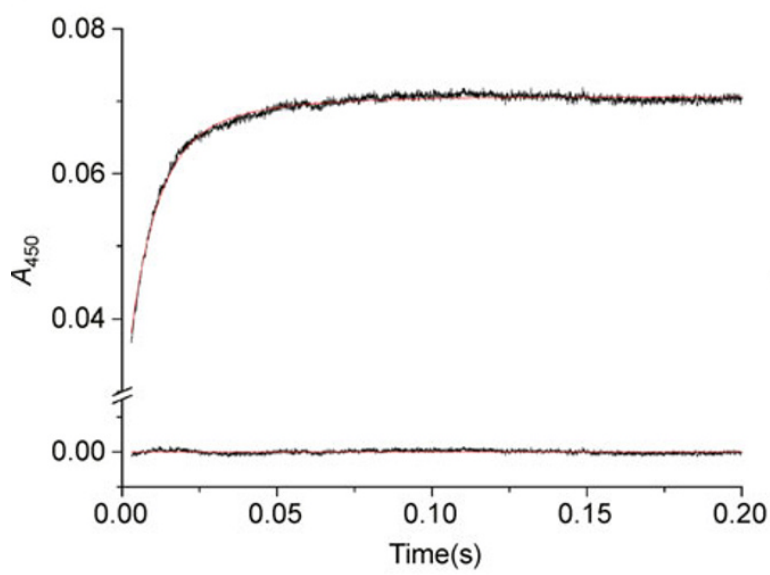

E

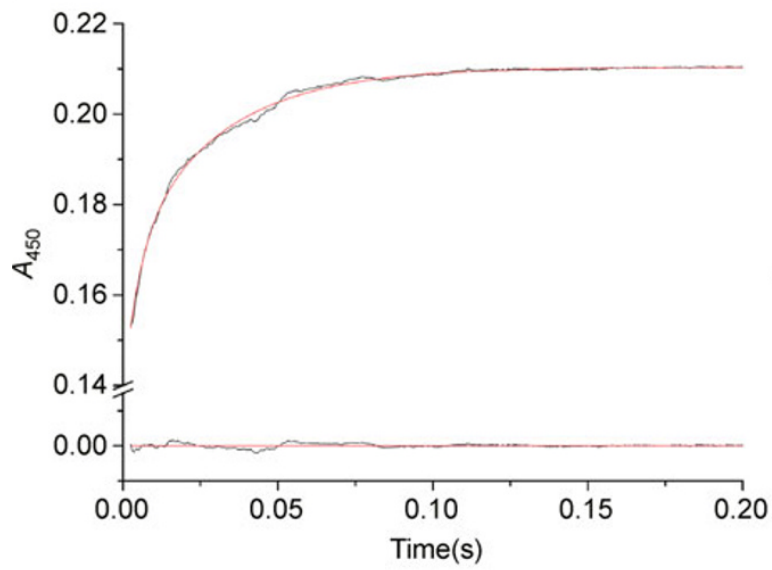

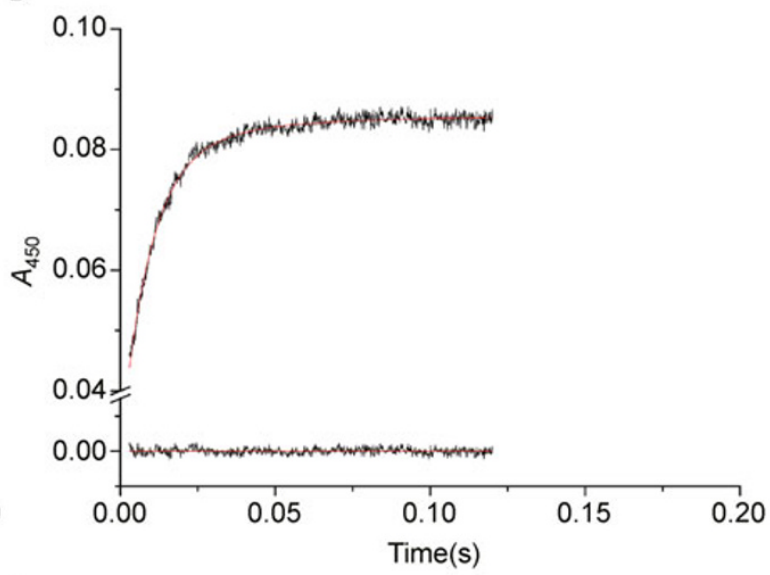

D

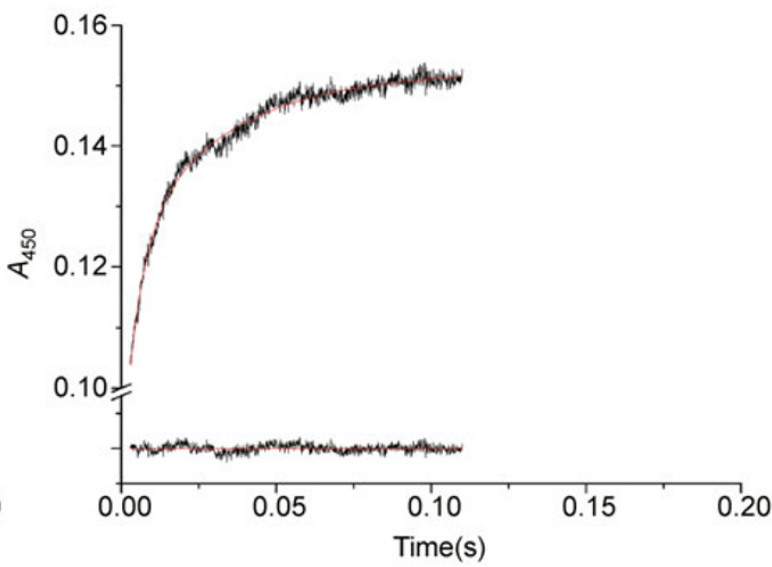

F

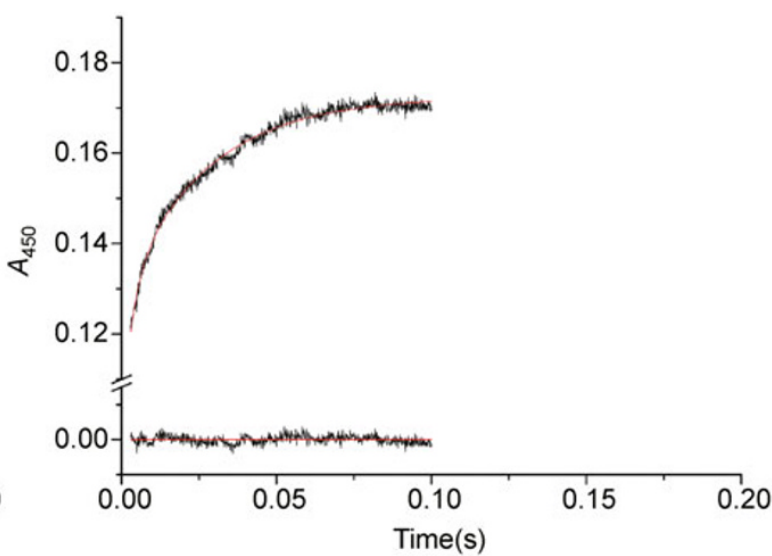

Figure 1. Time courses at $30^{\circ} \mathrm{C}, \mathrm{pH} 7.4$ for Fe"-CO complex formation monitored at $\mathbf{4 5 0} \mathrm{nm}$ for P450 $\mathrm{BM}^{\mathrm{B}}$. (A) Laurate in $50 \mathrm{mmol} / \mathrm{L}$ Tris, which required a single exponential $\left(k_{\mathrm{f}}=53.1 \mathrm{~s}^{-1}\right)$ to fit the data. (B) Laurate in $100 \mathrm{mmol} / \mathrm{L}$ phosphate, which required a double exponential to fit contributions from the fast phase $\left(k_{\mathrm{f}}=108 \mathrm{~s}^{-1}\right)$ and a denatured phase $\left(k_{\mathrm{d}}=30 \mathrm{~s}^{-1}\right)$, the fast phase accounting for $88 \%$ of the amplitude. (C) Myristate in $50 \mathrm{mmol} / \mathrm{L}$ Tris (single exponential fit: $k_{\mathrm{f}}=98 \mathrm{~s}^{-1}$ ). (D) Myristate in $100 \mathrm{mmol} / \mathrm{L}$ phosphate (double exponential fit: $k_{\mathrm{f}}=226 \mathrm{~s}^{-1}, 56 \% ; k_{\mathrm{d}}=33 \mathrm{~s}^{-1}, 44 \%$ ). (E) Palmitate in $50 \mathrm{mmol} / \mathrm{L}$ Tris (double exponential fit: $k_{\mathrm{f}}=218 \mathrm{~s}^{-1}, 52 \% ; k_{\mathrm{d}}=31 \mathrm{~s}^{-1}, 48 \%$ ). (F) Palmitate in $100 \mathrm{mmol} / \mathrm{L}$ phosphate (double exponential fit: $k_{\mathrm{f}}=306 \mathrm{~s}^{-1}, 41 \%$; $\left.k_{\mathrm{d}}=37 \mathrm{~s}^{-1}, 59 \%\right)$. 
Table 2 Values of $k_{\mathrm{f}}\left(\mathrm{s}^{-1}\right)$, the rate constant for the formation of the $\mathrm{Fe}$ "-CO form of $\mathrm{P}^{\prime \prime} 50_{\mathrm{BM} 3}$ complexed with laurate, myristate and palmitate in different concentrations of Tris and phosphate buffers $\left(30^{\circ} \mathrm{C}, \mathrm{pH} 7.4\right)$

\begin{tabular}{lcccccccc}
\hline & \multicolumn{4}{c}{$k_{\mathrm{f}}\left(\mathrm{s}^{-1}\right)$ in phosphate $(\mathrm{mmol} / \mathrm{L})$} & \multicolumn{4}{c}{$k_{\mathrm{f}}\left(\mathrm{s}^{-1}\right)$ in Tris $(\mathrm{mmol} / \mathrm{L})$} \\
& 10 & 25 & 100 & 200 & 300 & 50 & 100 & 250 \\
\hline Laurate & - & - & $107 \pm 21$ & $117 \pm 8$ & $118 \pm 12$ & $58 \pm 7.6$ & $51 \pm 9.8$ & $50 \pm 3.7$ \\
Myristate & - & - & $223 \pm 23$ & - & - & $102 \pm 7$ & - & - \\
Palmitate & $234 \pm 7$ & $305 \pm 19$ & $303 \pm 24$ & $288 \pm 23$ & $279 \pm 24$ & $227 \pm 15$ & $218 \pm 33$ & $217 \pm 39$ \\
\hline
\end{tabular}

Data are given as mean \pm SD with SD of data from at least three independent experiments.

$(234 \pm 7) \mathrm{s}^{-1}$ in $10 \mathrm{mmol} / \mathrm{L}$ phosphate. This was comparable to the value in $250 \mathrm{mmol} / \mathrm{L}$ Tris despite the much reduced HS heme content.

\section{Chain length-dependent kinetic behavior of fatty acid oxidation by $\mathrm{P}^{450_{\mathrm{BM} 3}}$}

Laurate oxidation showed Michaelis-Menten kinetics in both

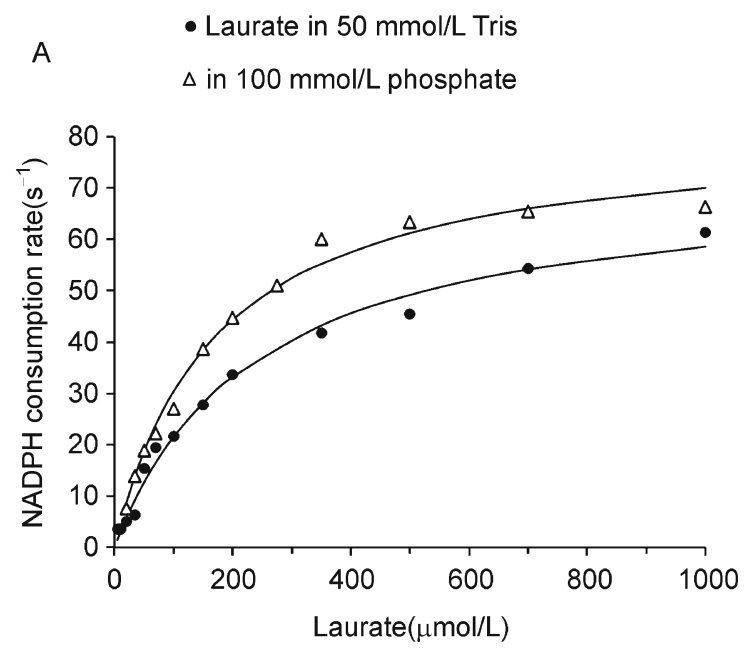

C $\Delta$ Palmitate in $50 \mathrm{mmol} / \mathrm{L}$ Tris

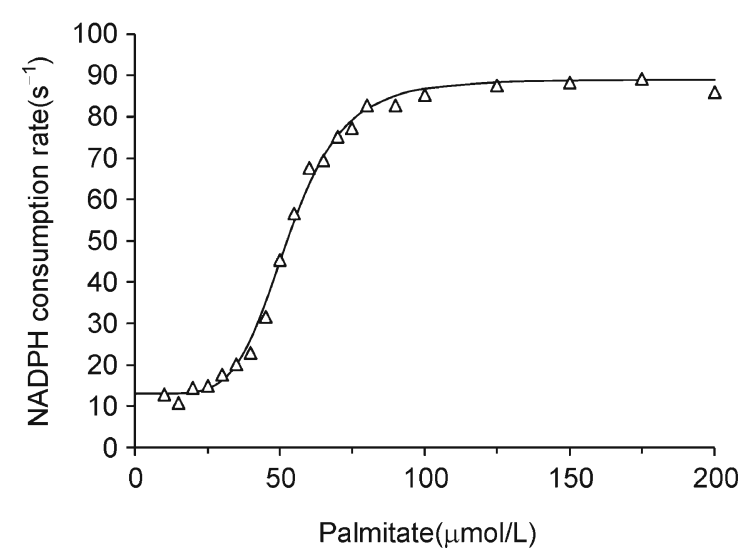

$50 \mathrm{mmol} / \mathrm{L}$ Tris and $100 \mathrm{mmol} / \mathrm{L}$ phosphate (Fig. 2A), with higher apparent $k_{\text {cat }}$ and lower apparent $K_{M}$ values in phosphate (Table 3). Myristate oxidation showed a slight deviation from Michaelis-Menten kinetics in $50 \mathrm{mmol} / \mathrm{L}$ Tris, but the data could be fitted satisfactorily to a hyperbolic function (Fig. 2B); fitting to the Hill equation gave an $n$ value of 1.2. As with laurate oxidation, $k_{\text {cat }}$ was higher in $100 \mathrm{mmol} / \mathrm{L}$ phosphate than in $50 \mathrm{mmol} / \mathrm{L}$ Tris although $K_{\mathrm{M}}$ was only

B $\quad$ Myristate in $50 \mathrm{mmol} / \mathrm{L}$ Tris

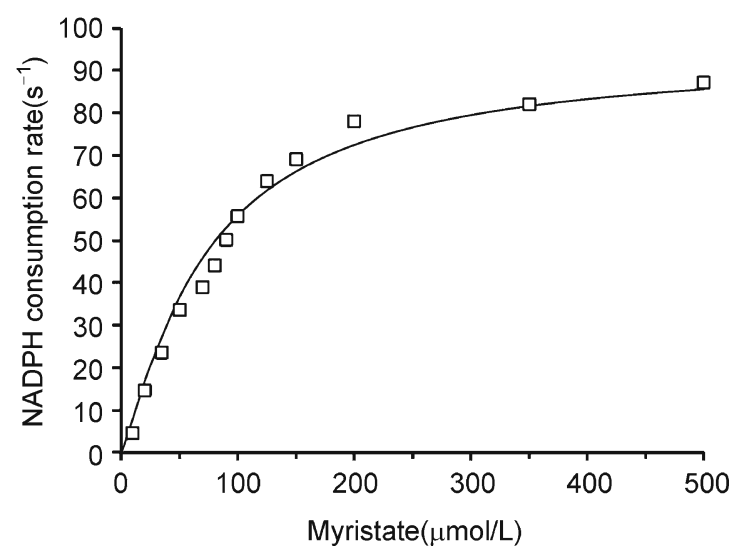

D $\Delta$ Palmitate in $100 \mathrm{mmol} / \mathrm{L}$ phosphate

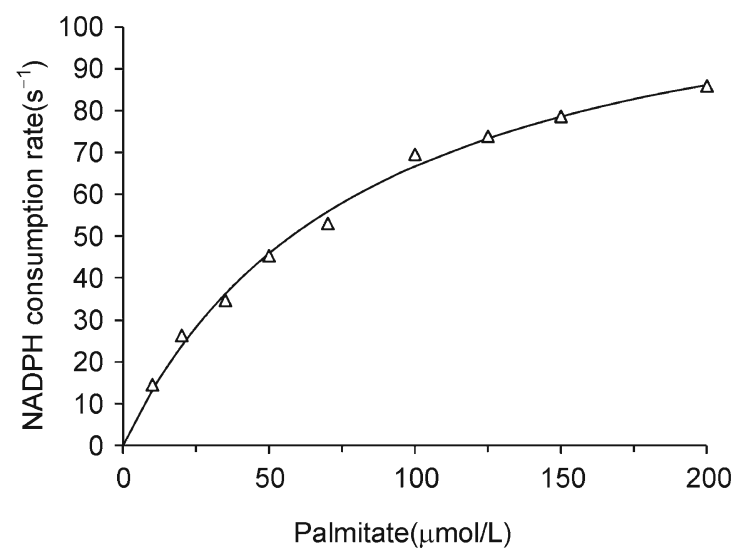

Figure 2. Kinetic titrations of $\mathrm{P}^{4} 50_{\mathrm{BM} 3}$ at $30^{\circ} \mathrm{C}, \mathrm{pH}$ 7.4. (A) With laurate in $50 \mathrm{mmol} / \mathrm{L}$ Tris and $100 \mathrm{mmol} / \mathrm{L}$ phosphate. (B) With myristate in $50 \mathrm{mmol} / \mathrm{L}$ Tris. (C) With palmitate in $50 \mathrm{mmol} / \mathrm{L}$ Tris. (D) With palmitate in $100 \mathrm{mmol} / \mathrm{L}$ phosphate. The enzyme concentration was $0.1 \mu \mathrm{mol} / \mathrm{L}$. All data were fitted to hyperbolic functions except for $(\mathrm{C})$ where a Hill equation with an intercept was used. 
Table 3 Apparent kinetic parameters for the oxidation of laurate, myristate and palmitate in $50 \mathrm{mmol} / \mathrm{L}$ Tris and $100 \mathrm{mmol} / \mathrm{L}$ phosphate $\left(30^{\circ} \mathrm{C}, \mathrm{pH} 7.4\right)$ with the enzyme concentration at $0.1 \mu \mathrm{mol} / \mathrm{L}$

\begin{tabular}{lcccccc}
\hline & \multicolumn{3}{c}{$100 \mathrm{mmol} / \mathrm{L}$ phosphate } & \multicolumn{3}{c}{$50 \mathrm{mmol} / \mathrm{L}$ Tris } \\
& $k_{\mathrm{cat}}\left(\mathrm{s}^{-1}\right)$ & $K_{\mathrm{M} / \mathrm{H}}(\mu \mathrm{mol} / \mathrm{L})$ & $n$ & $k_{\mathrm{cat}}\left(\mathrm{s}^{-1}\right)$ & $K_{\mathrm{M} / \mathrm{H}}(\mu \mathrm{mol} / \mathrm{L})$ & $n$ \\
\hline Laurate & $82 \pm 2.0$ & $170 \pm 12$ & 1 & $73 \pm 2.5$ & $239 \pm 21$ & 1 \\
Myristate & $138 \pm 3.1$ & $70 \pm 2.7$ & 1 & $94 \pm 3.4$ & $79 \pm 5.0$ & 1.2 \\
Palmitate & $122 \pm 5.9$ & $83 \pm 9.0$ & 1 & $87 \pm 1.4$ & $52 \pm 1.0$ & $4.8 \pm 0.3^{*}$ \\
\hline
\end{tabular}

Data are given as mean \pm SD with SD of data from at least three independent experiments. ${ }^{*}$ : with an intercept of $12 \mathrm{~s}^{-1}$.

marginally lower (Table 3).

Palmitate oxidation showed different behavior. In $100 \mathrm{mmol} / \mathrm{L}$ phosphate (Fig. 2D) typical Michaelis-Menten behavior was observed $\left(k_{\text {cat }}=[122 \pm 5.9] \mathrm{s}^{-1}, K_{\mathrm{M}}=[83 \pm\right.$ $9.0] \mu \mathrm{mol} / \mathrm{L}$ ), but in $50 \mathrm{mmol} / \mathrm{L}$ Tris the kinetics were sigmoidal, and fitting to a Hill equation with an intercept gave a $k_{\text {cat }}$ value of $(87 \pm 1.4) \mathrm{s}^{-1}$ and a $K_{\mathrm{H}}$ value of $(52 \pm 1.0) \mu \mathrm{mol} / \mathrm{L}$ (Fig. $2 \mathrm{C}$ and Table 3). The Hill coefficient, $n$, was 4.8 and the intercept was $12 \mathrm{~s}^{-1}$. Under our normal conditions for steady state $\mathrm{NADPH}$ consumption rate assays $\left(0.1 \mu \mathrm{mol} / \mathrm{L} \mathrm{P} 450_{\mathrm{BM} 3}\right.$, $200 \mu \mathrm{mol} / \mathrm{L}$ palmitate), the rates in these two buffers were similar, and the unusual kinetic behavior observed at lower substrate concentrations was not apparent.

The product distributions for all three fatty acids were unaffected by the different buffer conditions (data not shown).

\section{Sigmoidal kinetics for palmitate oxidation by $\mathrm{P}^{450_{\mathrm{BM}}}$ is dependent on ionic strength}

Kinetic titrations with palmitate in $10,25,50$ and $75 \mathrm{mmol} / \mathrm{L}$ phosphate buffer showed dramatic changes as the phosphate concentration was lowered (Fig. 3 and Table 4). Michaelis-Menten kinetics was observed in $75 \mathrm{mmol} / \mathrm{L}$ phosphate (Fig. 3A), with apparent $k_{\text {cat }}$ and $K_{\mathrm{M}}$ values that were virtually identical to those in $100 \mathrm{mmol} / \mathrm{L}$ phosphate. The data for $50 \mathrm{mmol} / \mathrm{L}$ phosphate could be fitted satisfactorily to a hyperbolic function, but the deviations were sufficient that the Hill equation gave a better fit (Fig. 3B, $n=1.4$ ). Sigmoidal kinetics with apparent intercepts was observed in $25 \mathrm{mmol} / \mathrm{L}$ (Fig. 3C, $n=4.8$ ) and $10 \mathrm{mmol} / \mathrm{L}$ phosphate (Fig. 3E, $n=4.0$ ). Both $k_{\text {cat }}$ and $K_{\mathrm{H}}$ decreased as the phosphate concentration was lowered (Table 4).

The effect of ionic strength on the kinetics was examined in $10 \mathrm{mmol} / \mathrm{L}$ phosphate containing $15 \mathrm{mmol} / \mathrm{L} \mathrm{Na}_{2} \mathrm{CO}_{3}$ or $\left(\mathrm{NH}_{4}\right)_{2} \mathrm{SO}_{4}$. Addition of $\mathrm{Na}_{2} \mathrm{CO}_{3}$ increased both $k_{\text {cat }}$ and $K_{\mathrm{H}}$ while the Hill coefficient was lowered slightly (Fig. $3 \mathrm{~F}$ and Table 4). The effect of $\left(\mathrm{NH}_{4}\right)_{2} \mathrm{SO}_{4}$ was more pronounced (Fig. 3D), with both $k_{\text {cat }}$ and $K_{\mathrm{H}}$ being raised above their corresponding values in $25 \mathrm{mmol} / \mathrm{L}$ phosphate, and the Hill coefficient was reduced to 3.7 from 4.8 in $25 \mathrm{mmol} / \mathrm{L}$ phosphate. The results are consistent with an ionic strength effect. The $\mathrm{pK}_{\mathrm{b}}$ of $\mathrm{CO}_{3}^{2-}$ leads to partial hydrolysis at $\mathrm{pH} 7.4$ to form $\mathrm{HCO}_{3}^{-}$, such that the ionic strength is lower than that for an identical concentration of $\left(\mathrm{NH}_{4}\right)_{2} \mathrm{SO}_{4}$ which does not hydrolyze to $\mathrm{HSO}_{4}^{-}$. Phosphate buffer is a mixture of $\mathrm{H}_{2} \mathrm{PO}_{4}^{-}$ and $\mathrm{HPO}_{4}^{2-}$ at $\mathrm{pH}$ 7.4. The $\mathrm{p} K_{\mathrm{b}}$ of $\mathrm{HPO}_{4}^{2-}$ is such that the ionic strength of $25 \mathrm{mmol} / \mathrm{L}$ phosphate is higher than a mixture of $10 \mathrm{mmol} / \mathrm{L}$ phosphate and $15 \mathrm{mmol} / \mathrm{L} \mathrm{Na}_{2} \mathrm{CO}_{3}$, but lower than the mixture of $10 \mathrm{mmol} / \mathrm{L}$ phosphate with $15 \mathrm{mmol} / \mathrm{L}\left(\mathrm{NH}_{4}\right)_{2} \mathrm{SO}_{4}$. Sigmoidal behavior was also attenuated in a mixture of $50 \mathrm{mmol} / \mathrm{L}$ Tris and $25 \mathrm{mmol} / \mathrm{L}$ phosphate. The Hill coefficient was lowered to 2.3 , while both the apparent $k_{\mathrm{cat}}$ and $K_{\mathrm{H}}$ were raised and approached their values in $50 \mathrm{mmol} / \mathrm{L}$ phosphate (Table 4 ).

It was notable that kinetic titrations displaying sigmoidal behavior had an intercept that varied with the conditions. The background NADPH consumption rate in the absence of a substrate was ca. $0.5 \mathrm{~s}^{-1}$ under all conditions studied. As shown in Fig. 3, fits for the low ionic strength data using this background rate as the intercept were less satisfactory than when the intercept was allowed to vary. The fitted intercepts, which are unlikely to be real, probably arose from difficulties in determining NADPH consumption rates precisely at low palmitate concentrations. The leveling-off of NADPH consumption rates in the $10-30 \mu \mathrm{mol} / \mathrm{L}$ range is likely to be the prelude to a decrease towards the background rate as the palmitate concentration approached zero.

Palmitic acid is a relatively abundant linear fatty acid in Bacillus megaterium membranes but branched fatty acids are more common, and there are suggestions that the latter may be the natural substrates of $\mathrm{P}^{4} 50_{\text {BM }}$ (Cryle et al., 2006). Kinetic titrations with 13-methylmyristic acid, the most abundant branched fatty acid in Bacillus membranes (Mizushima et al., 1966), showed typical Michaelis-Menten kinetics in $10 \mathrm{mmol} / \mathrm{L}$ phosphate $\left(k_{\mathrm{cat}}=[36 \pm 1.5] \mathrm{s}^{-1}, K_{\mathrm{M}}=[33\right.$ $\pm 2.1] \mu \mathrm{mol} / \mathrm{L})$.

\section{Fatty acid binding to $\mathrm{P}^{450_{\mathrm{BM}}}$}

Binding titrations of the $\mathrm{P}_{45} 0_{\mathrm{BM}}$ heme domain with laurate showed hyperbolic behavior in $50 \mathrm{mmol} / \mathrm{L}$ Tris and $100 \mathrm{mmol} / \mathrm{L}$ phosphate, the dissociation constant, $K_{\mathrm{d}}$, being $(18.7 \pm 1.1) \mu \mathrm{mol} / \mathrm{L}$ and $(21.4 \pm 1.8) \mu \mathrm{mol} / \mathrm{L}$, respectively (Fig. 4A). Palmitate binding showed complex behavior, as with kinetic titrations. For the heme domain in $100 \mathrm{mmol} / \mathrm{L}$ phosphate there was a sharp initial rise in the difference spectrum followed by a slight drop (Fig. 5A), indicating two binding sites, the second of which had a smaller maximum absorbance change $\left(\Delta A_{\max }\right)$. The data were analyzed with a two-site sequential binding model 
A

$\Delta 75 \mathrm{mmol} / \mathrm{L}$ phosphate

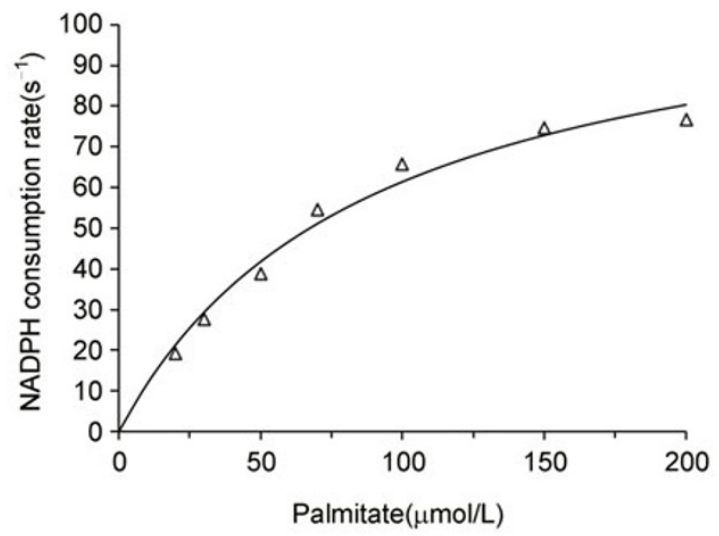

C

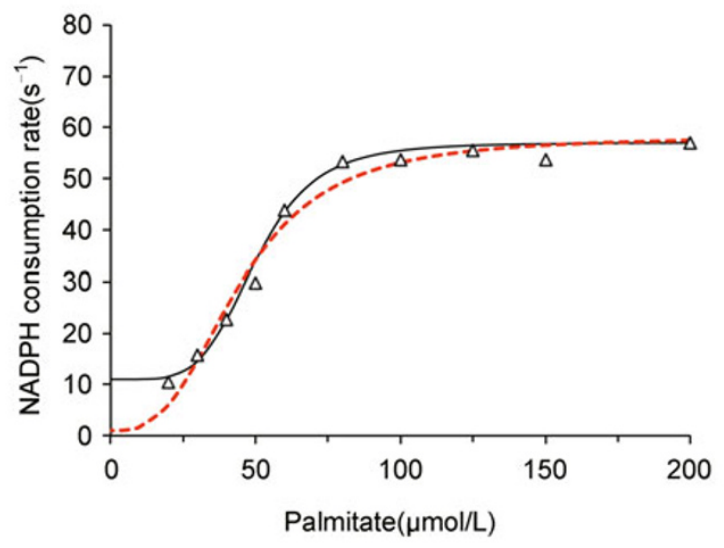

E

$\Delta 10 \mathrm{mmol} / \mathrm{L}$ phosphate

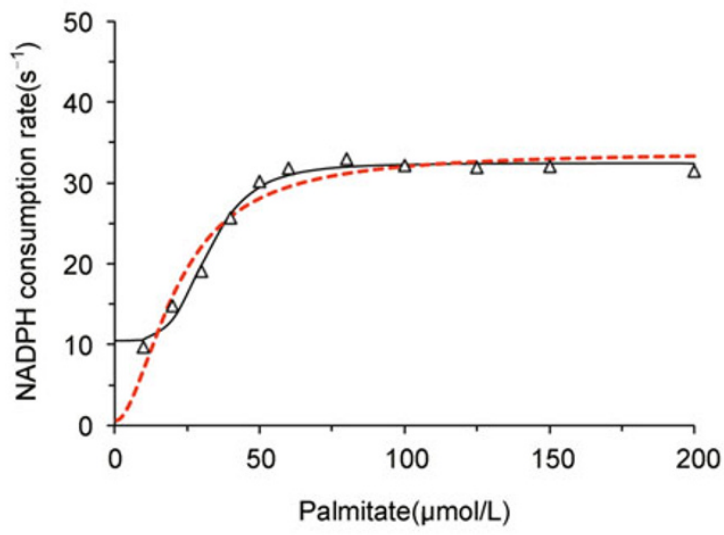

B

$\Delta 50 \mathrm{mmol} / \mathrm{L}$ phosphate

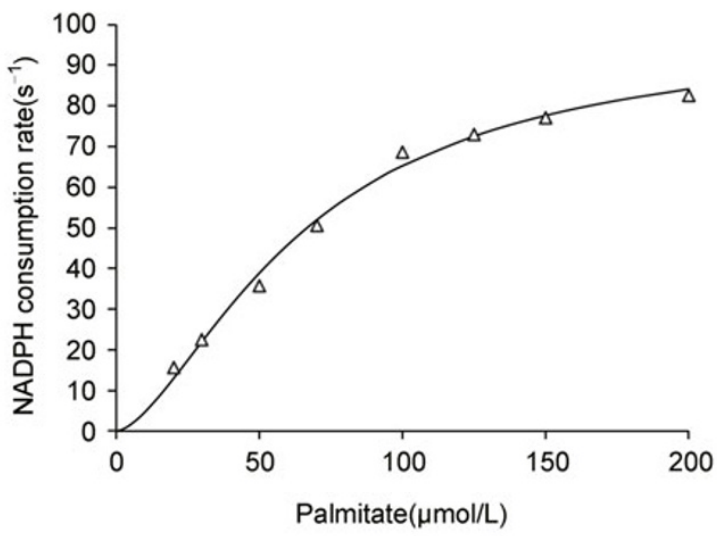

D $\Delta 10 \mathrm{mmol} / \mathrm{L}$ phosphate with $15 \mathrm{mmol} / \mathrm{L}$ sulfate

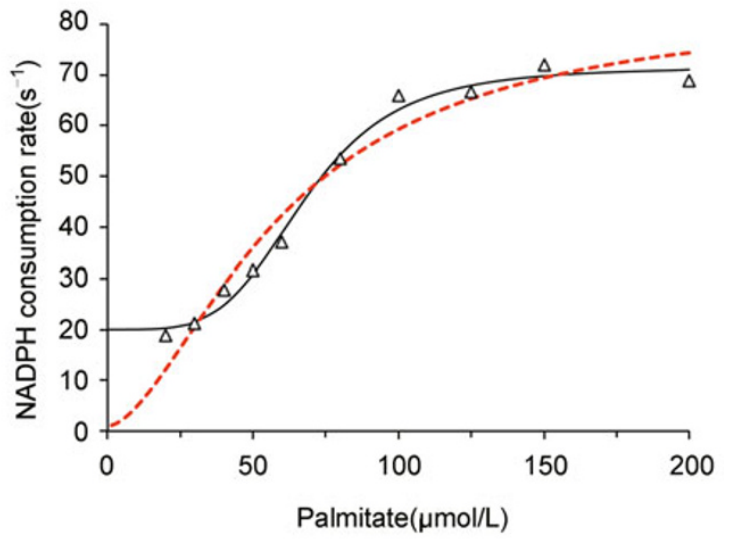

F $\Delta 10 \mathrm{mmol} / \mathrm{L}$ phosphate with $15 \mathrm{mmol} / \mathrm{L}$ carbonate

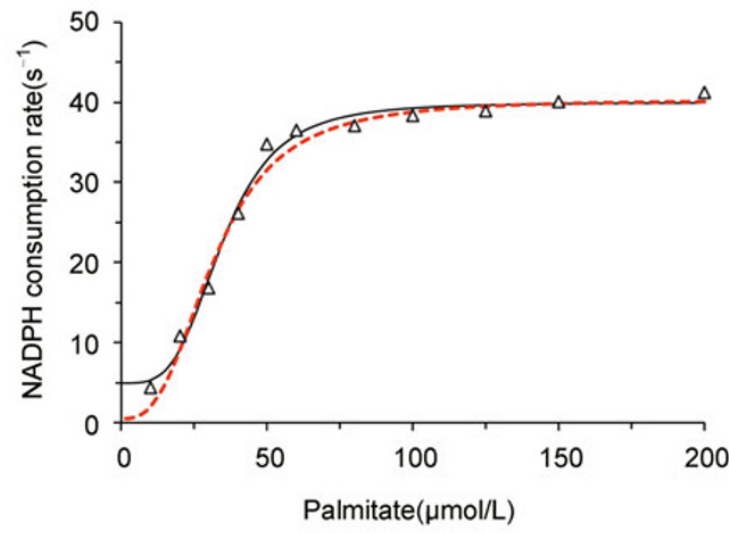

Figure 3. Kinetic titrations of $\mathbf{P} 450_{\mathrm{BM} 3} . \mathrm{P} 450_{\mathrm{BM} 3}(0.1 \mu \mathrm{mol} / \mathrm{L})$ with palmitate at $\mathrm{pH} 7.4,30^{\circ} \mathrm{C}$, showing the onset of sigmoidal behaviour at $50 \mathrm{mmol} / \mathrm{L}$ phosphate $(A-C)$, and in $10 \mathrm{mmol} / \mathrm{L}$ phosphate $(E)$ with added ammonium sulfate $(D)$ and sodium carbonate $(F)$ showing the effect of ionic strength. The data for low phosphate buffer concentrations, in panels (C-F), were fitted to a modified Hill equation with an intercept; black lines depict best fits where the intercept was allowed to vary, while fits using the background NADPH consumption rate of $0.5 \mathrm{~s}^{-1}$ in the absence of substrate as the intercept are shown as red dashed lines. 
Table 4 Apparent kinetic parameters for the oxidation of palmitate by $\mathrm{P}^{4} 50_{\mathrm{BM} 3}$ in different phosphate buffer concentrations and in mixtures with other compounds

\begin{tabular}{|c|c|c|c|c|}
\hline & $k_{\text {cat }}\left(\mathrm{s}^{-1}\right)$ & $K_{\mathrm{M} / \mathrm{H}}(\mu \mathrm{mol} / \mathrm{L})$ & $n$ & $v_{\mathrm{o}}\left(\mathrm{s}^{-1}\right)$ \\
\hline $10 \mathrm{mmol} / \mathrm{L}$ & $32 \pm 1.0$ & $31 \pm 1.3$ & 4.0 & 11 \\
\hline $25 \mathrm{mmol} / \mathrm{L}$ & $56 \pm 1.1$ & $50 \pm 1.3$ & 4.8 & 11 \\
\hline $50 \mathrm{mmol} / \mathrm{L}$ & $98 \pm 6.6$ & $65 \pm 7.2$ & 1.4 & - \\
\hline $75 \mathrm{mmol} / \mathrm{L}$ & $116 \pm 6.9$ & $89 \pm 11$ & 1 & - \\
\hline $100 \mathrm{mmol} / \mathrm{L}$ & $122 \pm 5.9$ & $83 \pm 9.0$ & 1 & - \\
\hline $10 \mathrm{mmol} / \mathrm{L}+15 \mathrm{mmol} / \mathrm{L} \mathrm{Na} \mathrm{CO}_{3}$ & $40 \pm 0.7$ & $35 \pm 1.3$ & 4.3 & 5 \\
\hline$+15 \mathrm{mmol} / \mathrm{L}\left(\mathrm{NH}_{4}\right)_{2} \mathrm{SO}_{4}$ & $72 \pm 1.8$ & $68 \pm 2.6$ & 3.7 & 20 \\
\hline $25 \mathrm{mmol} / \mathrm{L}+50 \mathrm{mmol} / \mathrm{L}$ Tris & $95 \pm 3.3$ & $62 \pm 3.0$ & 2.3 & 16 \\
\hline
\end{tabular}

The enzyme concentration was $0.1 \mu \mathrm{mol} / \mathrm{L}$. All data were obtained at $30^{\circ} \mathrm{C}, \mathrm{pH} 7.4$, and are given as mean $\pm \mathrm{SD}$ with SD of data from at least three independent experiments, $n$ : Hill coefficient, $v_{\mathrm{o}}$ : intercept.

A

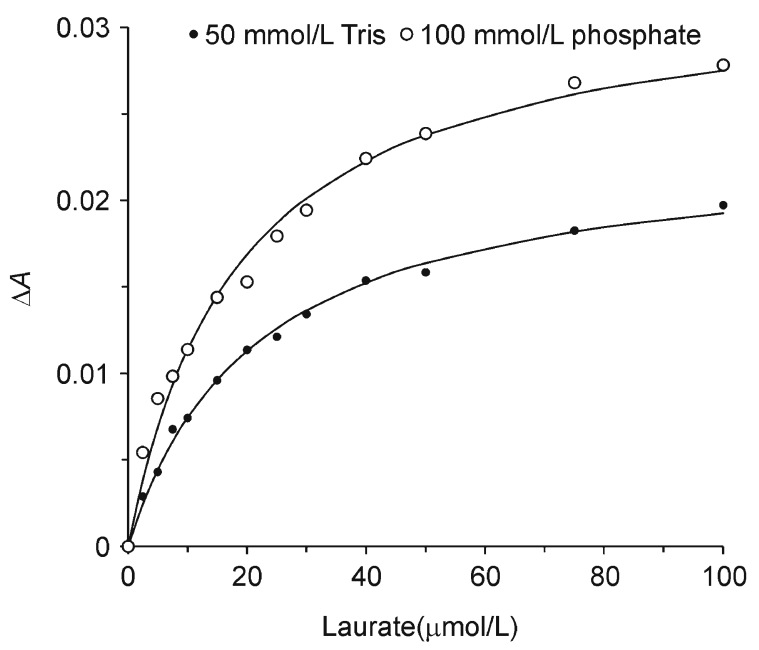

B

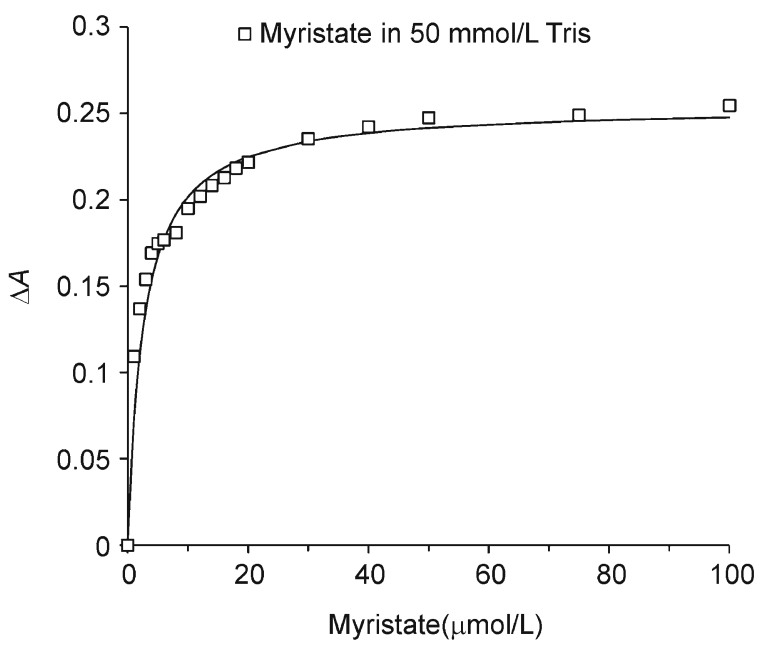

Figure 4. Plots of peak-to-trough separations in the difference spectra for binding titrations for the heme domain of $\mathrm{P}^{450_{\mathrm{BM} 3}}$ at $30^{\circ} \mathrm{C}$, pH 7.4. (A) Laurate in $50 \mathrm{mmol} / \mathrm{L}$ Tris and $100 \mathrm{mmol} / \mathrm{L}$ phosphate; the enzyme concentration in both buffers was $0.5 \mu \mathrm{mol} / \mathrm{L}$. (B) Myristate in $50 \mathrm{mmol} / \mathrm{L}$ Tris at an enzyme concentration of $5 \mu \mathrm{mol} / \mathrm{L}$. The laurate binding data were fitted to a rectangular hyperbola. The data for myristate binding showed a slight kink in the 10-12 $\mu \mathrm{mol} / \mathrm{L}$ concentration range but gave an acceptable fit to a hyperbolic function.

$$
\mathrm{E}+\mathrm{S} \rightleftharpoons \mathrm{ES} \stackrel{\mathrm{S}}{\rightleftharpoons} \mathrm{ES}_{2}
$$

in which binding of the first palmitate molecule was described by a quadratic equation and the second was treated as hyperbolic, leading to Eq. (1)

$$
\Delta A=\frac{\Delta A_{1}\left(b-\sqrt{b^{2}-4 a c}\right)}{2 a[E]}+\frac{\Delta A_{2}[S]\left(b-\sqrt{b^{2}-4 a c}\right)}{2 a K_{2}[E]}
$$

where

$$
\begin{aligned}
& a=\left(K_{2}+[\mathrm{S}]\right)\left(K_{2}+2[\mathrm{~S}]\right) \\
& b=K_{2}^{2}[\mathrm{~S}]+K_{2}[\mathrm{~S}]^{2}+K_{2}^{2}[\mathrm{E}]+2 K_{2}[\mathrm{E}][\mathrm{S}]+K_{1} K_{2}^{2} \\
& c=K_{2}^{2}[\mathrm{E}][\mathrm{S}]
\end{aligned}
$$

$\Delta A$ is the peak-to-trough difference $\left(A_{388}-A_{420}\right)$, scaled for dilution, in the difference spectrum at a given total substrate concentration [S]. $\Delta A_{1}$ and $\Delta A_{2}$ are the maximum absorbance differences for the two binding sites. $K_{1}$ and $K_{2}$ are the stoichiometric (macroscopic) dissociation constants of the first and second binding sites. [E] is the total enzyme concentration. Eq. (1) gave a good fit to the data (Fig. 5A), with $K_{1}=(1.02 \pm 0.02) \mu \mathrm{mol} / \mathrm{L}$ and $K_{2}=(3.34 \pm 0.04) \mu \mathrm{mol} / \mathrm{L}$. An equation assuming hyperbolic behavior for both sites gave a less satisfactory fit and over-estimated $K_{1}(1.60 \mu \mathrm{mol} / \mathrm{L})$ while underestimating $K_{2}(2.89 \mu \mathrm{mol} / \mathrm{L})$.

Palmitate binding to the heme domain in $50 \mathrm{mmol} / \mathrm{L}$ Tris gave a similar sharp initial rise followed by a drop, but this was followed by another increase in the peak-to-trough difference (Fig. 6). This behavior cannot be accounted for using a 2-site model. A 3-site model would reproduce the overall shape of 
A $\Delta$ Heme domain in $100 \mathrm{mmol} / \mathrm{L}$ phosphate

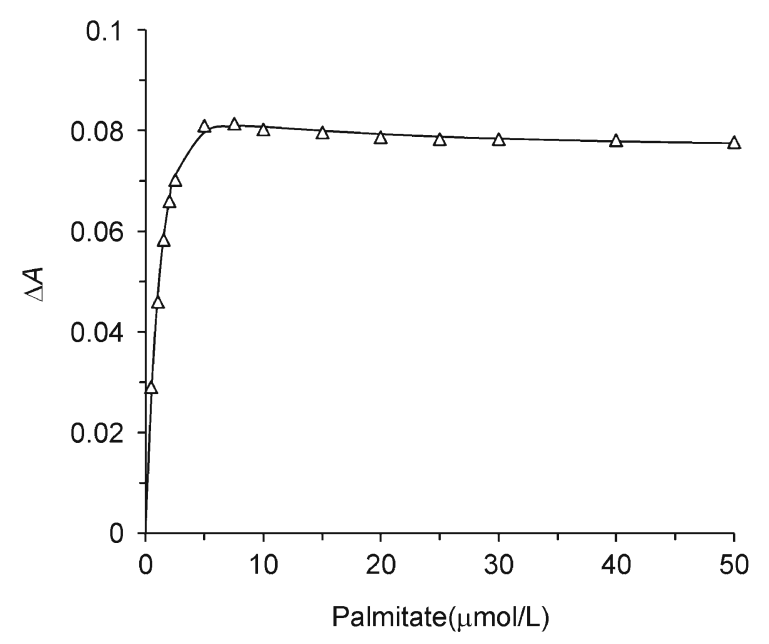

C $\Delta$ Full-length $\mathrm{P} 450_{\mathrm{BM} 3}$ in $50 \mathrm{mmol} / \mathrm{L}$ Tris

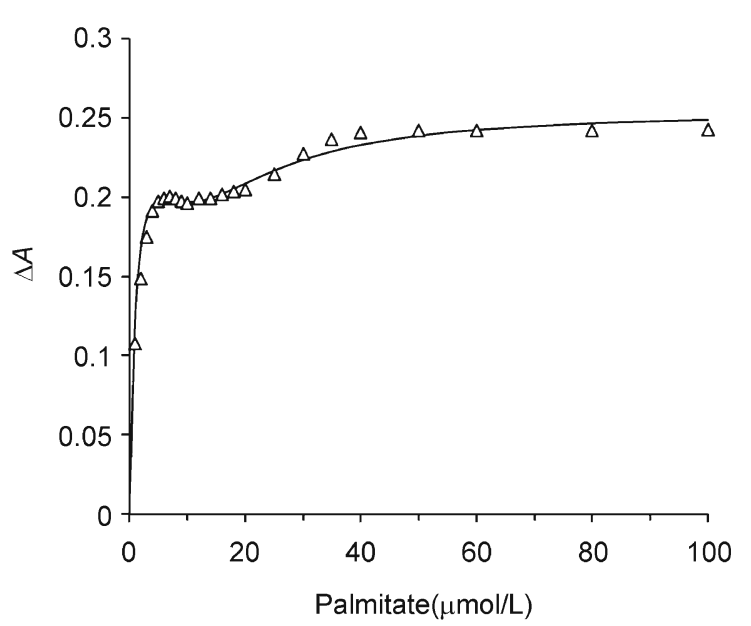

B $\Delta$ Heme domain in $50 \mathrm{mmol} / \mathrm{L}$ Tris

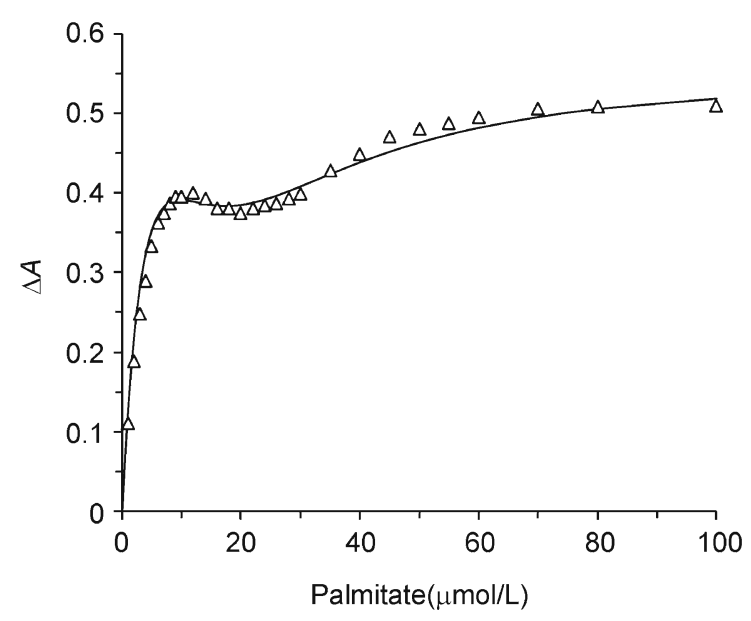

D $\Delta$ Heme domain in $10 \mathrm{mmol} / \mathrm{L}$ phosphate

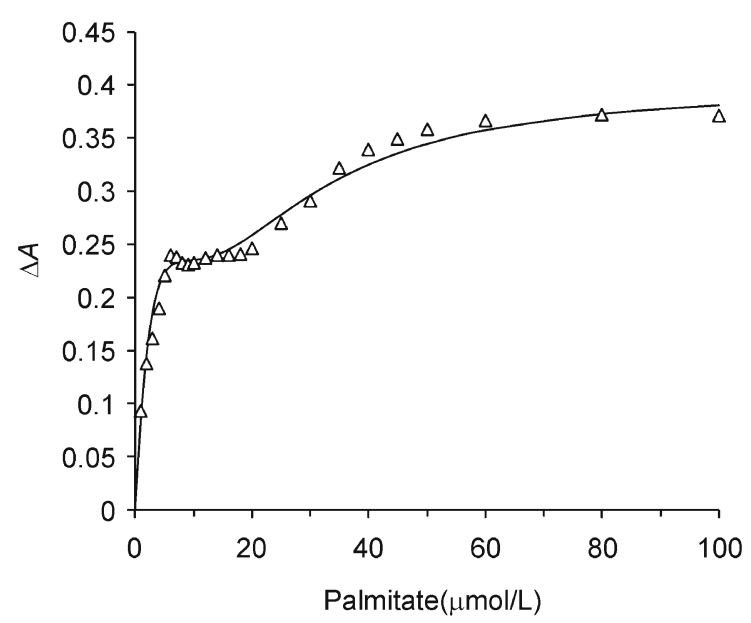

Figure 5. Palmitate binding titrations with $\mathrm{P}_{450}{ }_{\mathrm{BM} 3}$ at $30^{\circ} \mathrm{C}, \mathrm{pH} 7.4$ showing the plot of peak-to-trough separations $\left(A_{388}-\right.$ $\left.A_{420}\right)$, scaled for dilution. (A) For the heme domain $(1 \mu \mathrm{mol} / \mathrm{L})$ in $100 \mathrm{mmol} / \mathrm{L}$ phosphate. (B) For the heme domain $(5 \mu \mathrm{mol} / \mathrm{L})$ in $50 \mathrm{mmol} / \mathrm{L}$ Tris. (C) For the full-length enzyme $(2.5 \mu \mathrm{mol} / \mathrm{L})$ in $50 \mathrm{mmol} / \mathrm{L}$ Tris. (D) For the heme domain $(5 \mu \mathrm{mol} / \mathrm{L})$ in $10 \mathrm{mmol} / \mathrm{L}$ phosphate. The data in (A) were fitted to a two-site binding model while the complex behaviour in (B-D) required a four-site binding model.

the curve if binding of the second palmitate molecule led to a decrease in the absorbance difference (as observed in $100 \mathrm{mmol} / \mathrm{L}$ phosphate), while binding of the third palmitate gave rise to an increase. However, the increase in $\Delta A$ between $20 \mu \mathrm{mol} / \mathrm{L}$ and $70 \mu \mathrm{mol} / \mathrm{L}$ palmitate concentrations (Fig. $5 \mathrm{~B}$ ) required tight substrate binding. As the value of the binding constant of the third palmitate $\left(K_{3}\right)$ was lowered, the rapid increase in $\Delta A$ due to this third binding event, which by definition must lead to the observed $\Delta A_{\max }$ at saturation, eliminated the plateau/minimum between $10 \mu \mathrm{mol} / \mathrm{L}$ and $30 \mu \mathrm{mol} / \mathrm{L}$ palmitate concentrations (see Fig. S2-S4 for examples of curves for a 3-site model). If the plateau/ minimum was maintained by increasing $K_{3}$, the rise in $\Delta A$ towards $\Delta A_{\max }$ at saturation was too slow. Satisfactory fits to the data were not possible using a 3-site model. The observed behavior required a model with a minimum of four binding sites. For the simplest case of sequential four-site binding, i.e. 


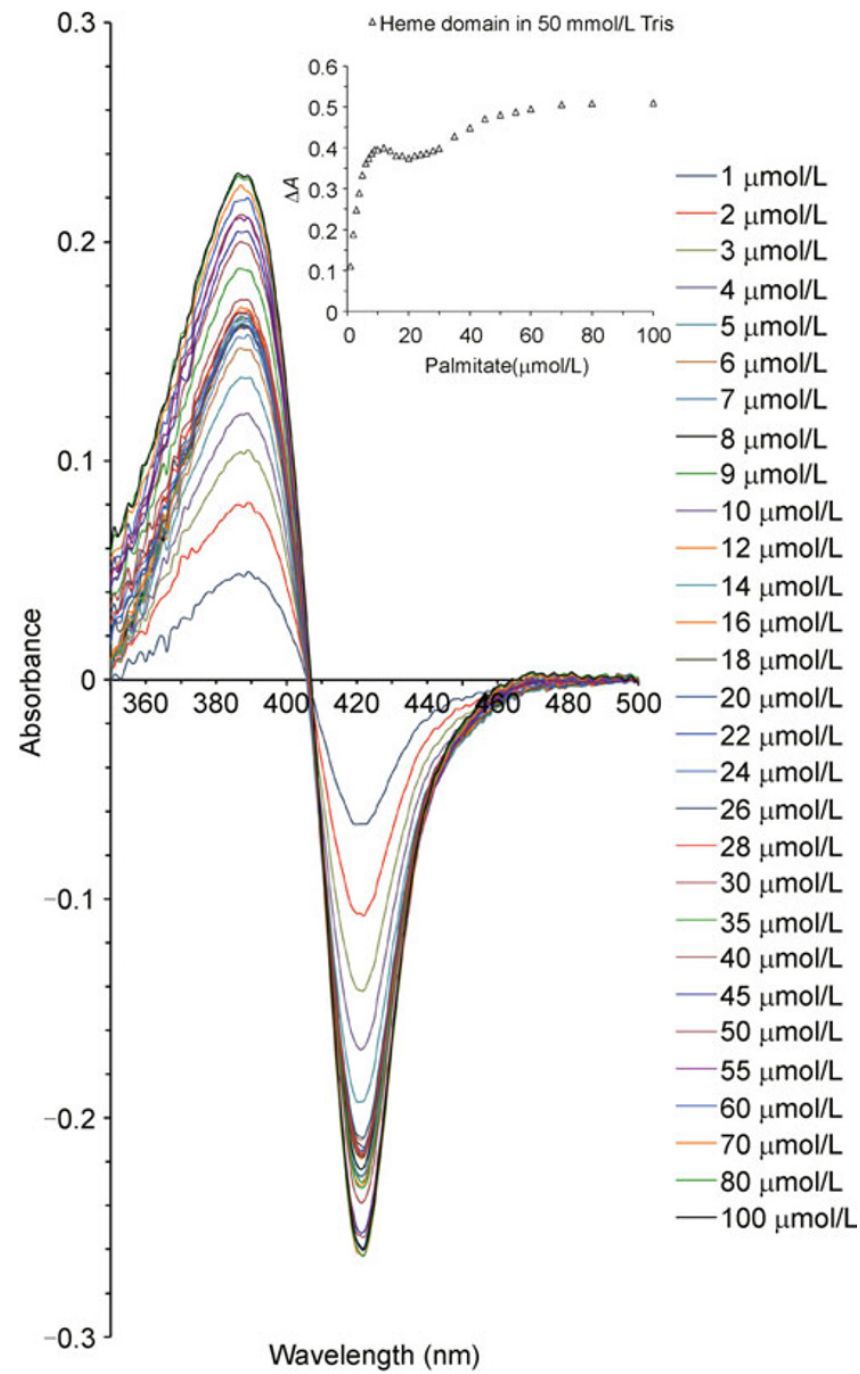

Figure 6. Difference spectra for the binding titration of palmitic acid with the $\mathrm{P} 450_{\mathrm{BM} 3}$ heme domain in $50 \mathrm{mmol} / \mathrm{L}$ Tris, $\mathrm{pH} 7.4$ at $30^{\circ} \mathrm{C}$. The protein concentration was $5 \mu \mathrm{mol} / \mathrm{L}$. The difference spectra in the presence of various total concentrations of palmitic acid, added from stock solutions in DMSO, are shown. The total concentration of DMSO added was $2 \%(\mathrm{~V} / \mathrm{V})$. Inset shows the plot of the peak-to-trough difference $\left(A_{388}-A_{420}\right)$, scaled for dilution, against the total substrate concentration.

$$
\mathrm{E}+\mathrm{S} \rightleftharpoons \mathrm{ES} \stackrel{\mathrm{S}}{\rightleftharpoons} \mathrm{ES}_{2} \stackrel{\mathrm{S}}{\rightleftharpoons} \mathrm{ES}_{3} \stackrel{\mathrm{S}}{\rightleftharpoons} \mathrm{ES}_{4}
$$

and assuming hyperbolic behavior for all four sites, Eq. (2) is obtained (Baas et al., 2004; Denisov et al., 2007):

$\Delta A=\frac{\Delta A_{1} \frac{[\mathrm{S}]}{K_{1}}+\Delta A_{2} \frac{([\mathrm{S}])^{2}}{K_{1} K_{2}}+\Delta A_{3} \frac{([\mathrm{S}])^{3}}{K_{1} K_{2} K_{3}}+\Delta A_{4} \frac{([\mathrm{S}])^{4}}{K_{1} K_{2} K_{3} K_{4}}}{\left(1+\frac{[\mathrm{S}]}{K_{1}}+\frac{([\mathrm{S}])^{2}}{K_{1} K_{2}}+\frac{([\mathrm{S}])^{3}}{K_{1} K_{2} K_{3}}+\frac{([\mathrm{S}])^{4}}{K_{1} K_{2} K_{3} K_{4}}\right)}$

$\Delta A$ is the peak-to-trough absorbance difference $\left(A_{388}-A_{420}\right)$, scaled for dilution, in the difference spectrum at a given total substrate concentration [S], and $\Delta A_{\mathrm{i}}$ and $K_{\mathrm{i}}$ are respectively the maximum absorbance difference and dissociation constant for the $i^{\text {th }}$ binding site. In this analysis $K_{\mathrm{i}}$ and $\Delta A_{\mathrm{i}}$ are treated purely as phenomenological constants that are averaged over all microscopic binding modes and spin state equilibria, and the difference between the concentrations of free substrate and total substrate is neglected (Baas et al., 2004; Roberts et al., 2005; Denisov et al., 2009). More detailed analyses, including random binding order and taking into account the difference between free and total substrate concentrations as well as the spin state equilibria, are possible but additional experiments and numerical solutions to the binding equations are required.

The minimum at ca. $18 \mu \mathrm{mol} / \mathrm{L}$ palmitate concentration in the absorbance difference plot (Fig. 5B) dictated that the second and third binding events had lower $\Delta A_{\max }$ than the first and fourth. With 8 variables and 30 data points it was necessary to limit the number of variables fitted per iteration to 
two or three over many cycles of iteration. The values listed in Table 5 gave a satisfactory fit to the data and showed that the first two binding sites had comparable binding strengths $\left(K_{1}=\right.$ $\left.[6.50 \pm 0.50] \mu \mathrm{mol} / \mathrm{L}, K_{2}=[10.0 \pm 1.51] \mu \mathrm{mol} / \mathrm{L}\right)$, whereas binding of the third palmitate molecule was weak $\left(K_{3}=[380 \pm\right.$ 30] $\mu \mathrm{mol} / L$ ) while the binding of the fourth molecule was strong $\left(K_{4}=[1.80 \pm 0.25] \mu \mathrm{mol} / \mathrm{L}\right)$ and also cooperative. Compared to a 3-site model, the additional site of low binding affinity had the effect of delaying the onset of tight binding of the final palmitate molecule such that the plateau/minimum in the titration curve was maintained while providing a steeper rise towards $\Delta A_{\max }$ at saturation.

Binding titrations in $10 \mathrm{mmol} / \mathrm{L}$ phosphate (Fig. 5D and $7 \mathrm{~A}$ ), where sigmoidal kinetics was also observed, showed similar behavior that was satisfactorily modeled by the 4-site equation. The derived parameters were also similar (Table 5), with the third and fourth binding sites showing weak and strong binding respectively $\left(K_{3}=[320 \pm 20] \mu \mathrm{mol} / \mathrm{L}, K_{4}=\right.$ $[1.61 \pm 0.22] \mu \mathrm{mol} / \mathrm{L})$. The main difference between the two sets of data was slight cooperativity for the binding of the second palmitate molecule in $10 \mathrm{mmol} / \mathrm{L}$ phosphate.

Although multiple palmitate binding sites were revealed for the heme domain, these could in principle be irrelevant for fulllength $\mathrm{P}_{450_{\mathrm{BM}}}$, which is an obligate dimer in its functional form (Neeli et al., 2005; Kitazume et al., 2007). However, titrations with the full-length protein in $50 \mathrm{mmol} / \mathrm{L}$ Tris showed virtually identical behavior to the heme domain (Fig. 7B). The data were satisfactorily fitted to the four-site model (Fig. 5C), with the third site again showing weak binding and the fourth cooperative binding (Table 5). Notably the first palmitate molecule was more tightly bound to the full-length protein than to the heme domain ( $1.20 \mathrm{vs} 6.50 \mu \mathrm{mol} / \mathrm{L})$, as was the third molecule (128 vs $380 \mu \mathrm{mol} / \mathrm{L}$ ). Tighter fatty acid binding by the full-length enzyme than the heme domain has been reported previously (Modi et al., 1995). As a result, the functional form of the enzyme would be saturated at a lower palmitate concentration than the heme domain.

Myristate binding to the heme domain showed deviation from hyperbolic behavior in $50 \mathrm{mmol} / \mathrm{L}$ Tris (Fig. 4B and Fig. S1), with a narrow plateau in the 10-12 $\mu \mathrm{mol} / \mathrm{L}$ myristate concentration range, but the increase in the peak-to-trough difference was not arrested as emphatically as for palmitate. Fitting to the Hill equation gave a $K_{H}$ value of $2.63 \mu \mathrm{mol} / \mathrm{L}$ and an $n$ value of 0.53 ; this apparent negative cooperativity is unlikely given the results from the kinetic titrations. We therefore ascribe the effects to the impact of the second and third myristate binding sites in a four-site model (similar to that for palmitate) occurring over a narrower range of substrate concentration. It was not possible, however, to analyze the data in further detail.

\section{DISCUSSION}

Fatty acid-bound $\mathrm{P} 450_{\mathrm{BM} 3}$ shifted towards $\mathrm{HS}$ heme with increasing ionic strength, either at higher buffer concentrations or on addition of $\mathrm{KCl}$. The maximum HS heme content increased with chain length. The palmitate-bound form was particularly sensitive to ionic strength, rising from $55 \% \mathrm{HS}$ in $10 \mathrm{mmol} / \mathrm{L}$ phosphate to $95 \%$ in $50 \mathrm{mmol} / \mathrm{L}$ phosphate. The heme spin state of P450 enzymes is commonly linked to the rate of the first electron transfer to the heme, a critical step in the catalytic cycle, because both parameters may vary with the positioning of the heme axial water ligand.

The first electron transfer is rate limiting for a number of bacterial P450 systems including P450 cam $_{\text {(CYP101A1) from }}$ Pseudomonas putida (Brewer and Peterson, 1988), CYP199A2 and CYP199A4 from Rhodopseudomonas palustris (Bell et al., 2010b, 2010c) and CYP101D1 from Novosphingobium aromaticivorans (Bell and Wong, 2007; Bell et al., 2010a; Yang et al., 2010). It has been shown that the first flavin-to-heme electron transfer, though one of the slower steps in the overall catalytic cycle, is not rate limiting for palmitate and arachidonate oxidation by $\mathrm{P}^{4} 50_{\mathrm{BM}}$ (Munro et al., 1996; Ost et al., 2003; Whitehouse et al., 2011). Our findings that $k_{\mathrm{f}}$ for palmitate was almost 2.5-times as high as $k_{\text {cat }}$ in both $50 \mathrm{mmol} / \mathrm{L}$ Tris and $100 \mathrm{mmol} / \mathrm{L}$ phosphate are in agreement. Similarly $k_{\mathrm{f}}$ was approximately twice as high as $k_{\text {cat }}$ for myristate in $100 \mathrm{mmol} / \mathrm{L}$ phosphate, but in $50 \mathrm{mmol} / \mathrm{L}$ Tris $k_{\mathrm{f}}$ and $k_{\mathrm{cat}}$ were very similar, and under these conditions the first electron transfer is rate limiting. For laurate the first electron transfer was rate limiting in both $50 \mathrm{mmol} / \mathrm{L}$ Tris and $100 \mathrm{mmol} / \mathrm{L}$ phosphate (Noble et al., 1999). In $50 \mathrm{mmol} / \mathrm{L}$ Tris and $100 \mathrm{mmol} / \mathrm{L}$ phosphate, the general trends in the heme spin state, $k_{\mathrm{f}}$ and $k_{\mathrm{cat}}$ are consistent with the enzyme/ substrate fit improving with chain length from laurate to palmitate (Munro et al., 1996). However, myristate shows a slightly higher $k_{\text {cat }}$ than palmitate (Maves et al., 1997; Yeom and Sligar, 1997) despite a lower $k_{\mathrm{f}}$, indicating that one or more subsequent steps in the catalytic cycle are faster with myristate.

The nature of the buffer had unexpected effects on $k_{\mathrm{f}}$. The $\mathrm{HS}$ heme content of laurate-bound $\mathrm{P}^{4} \mathrm{H}_{\mathrm{BM} 3}$ increased with buffer strength in Tris as well as phosphate (Table 2), but $k_{\mathrm{f}}$ did not change significantly. On the other hand, $k_{\mathrm{f}}$ was nearly twice as high in $100 \mathrm{mmol} / \mathrm{L}$ phosphate as in $50 \mathrm{mmol} / \mathrm{L}$ Tris for laurate and myristate, and $40 \%$ higher for palmitate despite the high spin heme content in the two buffers being virtually identical. With palmitate in $10 \mathrm{mmol} / \mathrm{L}$ phosphate the heme was $55 \% \mathrm{HS}$, yet $k_{\mathrm{f}}\left(234 \mathrm{~s}^{-1}\right)$ was identical to that in $250 \mathrm{mmol} / \mathrm{L}$ Tris $\left(95 \% \mathrm{HS}\right.$ ). Moreover, $k_{\mathrm{f}}$ reached $305 \mathrm{~s}^{-1}$ in $25 \mathrm{mmol} / \mathrm{L}$ phosphate - the same value as at $100 \mathrm{mmol} / \mathrm{L}$ phosphate. The data suggest that phosphate has a specific and pronounced effect in promoting the first electron transfer even at $10 \mathrm{mmol} / \mathrm{L}$, where the heme is only $55 \% \mathrm{HS}$. Phosphate may affect the conformation of the heme domain and thus the electronic properties of the heme, or interact with the reductase domain and the dimer interface. The $\mathrm{P} 450_{\mathrm{BM}}$ FMN domain has been shown to undergo structural changes on FMN binding that have been attributed to interaction of the 
A

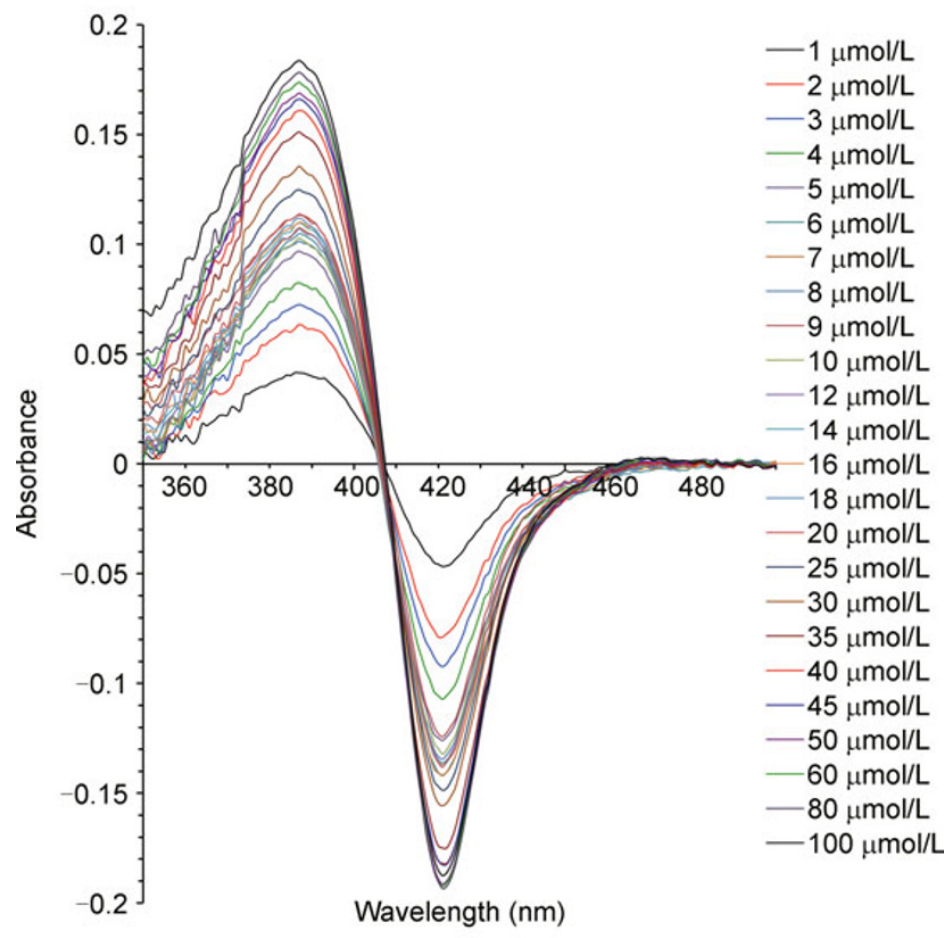

B

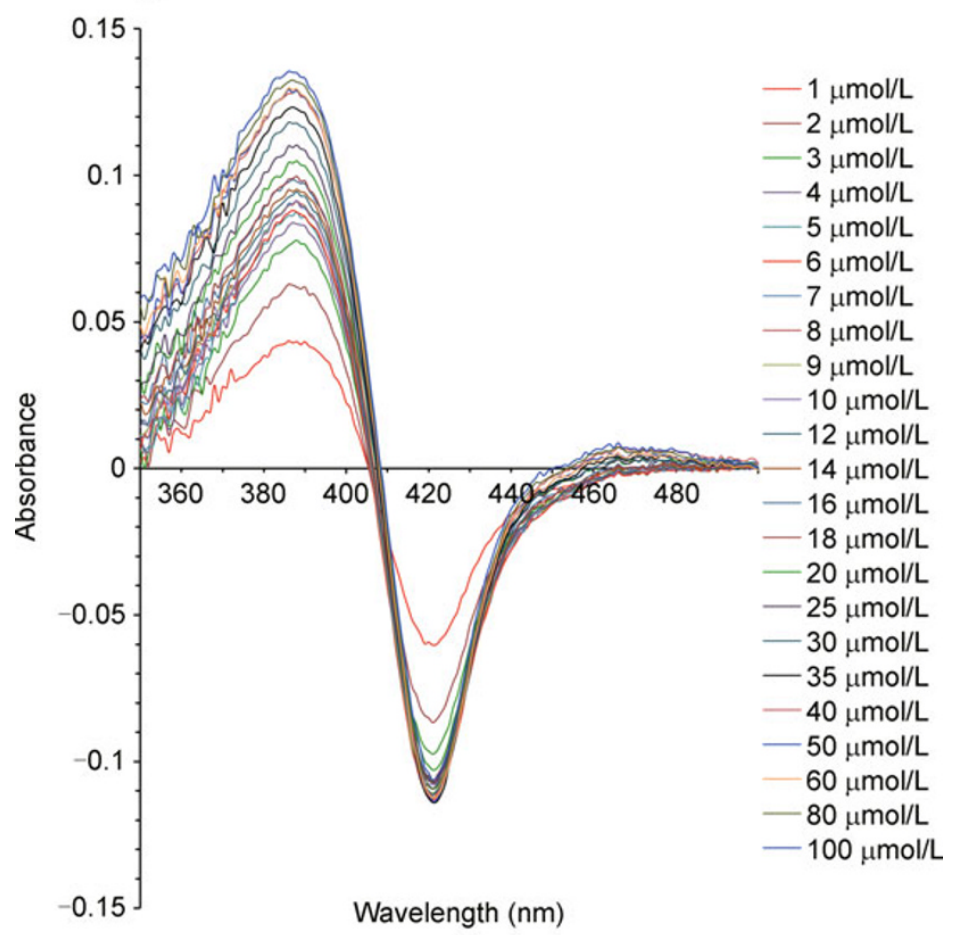

Figure 7. Difference spectra for binding titrations at $30^{\circ} \mathrm{C}, \mathrm{pH} 7.4$ of palmitic acid with $\mathbf{P} 450_{\mathrm{BM}}$. (A) The heme domain $(5 \mu \mathrm{mol} / \mathrm{L})$ in $10 \mathrm{mmol} / \mathrm{L}$ phosphate, and $(B)$ the full-length enzyme $(2.5 \mu \mathrm{mol} / \mathrm{L})$ in $50 \mathrm{mmol} / \mathrm{L}$ Tris. Palmitic acid was added from stock solutions in DMSO and the total concentration of DMSO added was $2 \%(\mathrm{v} / \mathrm{V})$. 
Table 5 Palmitate binding data for $\mathrm{P}^{4} 50_{\mathrm{BM} 3}$ in Tris and phosphate buffers

\begin{tabular}{lcccc}
\hline & $K_{1}(\mu \mathrm{mol} / \mathrm{L}) \Delta A_{1}$ & $K_{2}(\mu \mathrm{mol} / \mathrm{L}) \Delta A_{2}$ & $K_{3}(\mu \mathrm{mol} / \mathrm{L}) \Delta A_{3}$ & $K_{4}(\mu \mathrm{mol} / \mathrm{L}) \Delta A_{4}$ \\
\hline Heme domain P450 & & & \\
$10 \mathrm{~mm} 3$ & & & $320 \pm 25$ & $1.61 \pm 0.22$ \\
& $6.15 \pm 1.0$ & $4.70 \pm 0.07$ & $0.10 \pm 0.01$ & $0.41 \pm 0.02$ \\
$50 \mathrm{mmol} / \mathrm{L}$ Tris & $0.63 \pm 0.07$ & $0.09 \pm 0.02$ & $380 \pm 30$ & $1.80 \pm 0.25$ \\
& $6.50 \pm 0.50$ & $10.0 \pm 1.51$ & $0.05 \pm 0.01$ & $0.56 \pm 0.01$ \\
Full-length P450 & $0.92 \pm 0.08$ & $0.10 \pm 0.01$ & & $2.0 \pm 0.17$ \\
50 mmol/L Tris & $1.20 \pm 0.08$ & $10.5 \pm 0.15$ & $128 \pm 10$ & $0.25 \pm 0.01$ \\
\end{tabular}

All data were obtained at $30^{\circ} \mathrm{C}, \mathrm{pH} 7.4$, and are given as mean $\pm \mathrm{SD}$ with SD of data from at least three independent experiments. $K_{\mathrm{i}}$ and $\Delta A_{\mathrm{i}}$ are the dissociation constants and maximum absorbance differences for the $i^{\text {th }}$ binding site in a four-site binding model.

FMN-phosphate with the polypeptide (Haines et al., 2000). It is conceivable that external phosphate could have a comparable effect. Electron transfer in the functional dimeric form of the enzyme occurs from one molecule to the other (Neeli et al., 2005; Kitazume et al., 2007). Phosphate could participate in inter-domain interactions to induce conformational changes that promote electron transfer.

As the phosphate concentration is lowered, the unexpected trend observed for $k_{\mathrm{f}}$ with palmitate leads to the $k_{\mathrm{f}} / k_{\mathrm{cat}}$ ratio increasing from 2.5 at $100 \mathrm{mmol} / \mathrm{L}$ phosphate to 5.5 at $25 \mathrm{mmol} / \mathrm{L}$ and 7.1 at $10 \mathrm{mmol} / \mathrm{L}$. These values indicate that the first electron transfer plays a less important role in controlling the palmitate turnover activity of $\mathrm{P} 450_{\mathrm{BM}}$ as the phosphate concentration is lowered. Other steps in the catalytic cycle, such as the second electron transfer and product release, have become slower at these physiologically relevant phosphate concentrations.

Sigmoidal kinetics and substrate binding have been reported for non-natural substrates with wild-type $\mathrm{P} 450_{\mathrm{BM}}$ and mutants but not for fatty acid oxidation. The chain length and ionic strength dependence observed here was particularly unexpected. One possible origin is aggregation and eventual micelle formation as the critical micelle concentration (CMC) of fatty acids is expected to decrease as the chain length increases. The $\mathrm{CMC}$ at $30^{\circ} \mathrm{C}$ of the potassium salts of laurate, myristate and palmitate in aqueous solution is $27 \mathrm{mmol} / \mathrm{L}, 7 \mathrm{mmol} / \mathrm{L}$ and $3 \mathrm{mmol} / \mathrm{L}$, respectively (Malik and Jain, 1967). The CMC drops as ionic strength increases, e.g. to $15 \mathrm{mmol} / \mathrm{L}$ for laurate at $30 \mathrm{mmol} / \mathrm{L} \mathrm{NaCl}$, but it is highly unlikely that micelle formation is a factor at $<50 \mu \mathrm{mol} / \mathrm{L}$ palmitate in $10 \mathrm{mmol} / \mathrm{L}$ phosphate or $50 \mathrm{mmol} / \mathrm{L}$ Tris. If fatty acid aggregation and micelle formation were the dominant influence, increasing deviations would be expected at higher ionic strengths, contrary to experimental observations.

Comparison of the kinetic and substrate binding titrations suggests that the apparent intercepts in kinetic titrations might arise from difficulties in determining the rates at the lowest substrate concentrations $(<10 \mu \mathrm{mol} / \mathrm{L})$, masking the initial rise in rate (due to binding of the first palmitate molecule). This interpretation requires that binding of the second and third palmitates is inhibitory, leading to a plateau similar to those observed in palmitate binding titrations, and that cooperative binding of the fourth palmitate gives the final rate rise towards $k_{\text {cat }}$. The mechanism by which four palmitate molecules could bind to each monomer of dimeric full-length $\mathrm{P} 40_{\mathrm{BM}}$ or the heme domain is not clear. Crystal structures of the heme domain complexed with a fatty acid or derivative show only one substrate molecule in the active site, and in all cases the heme iron is penta-coordinate and almost certainly high spin (Hasemann et al., 1995; Li and Poulos, 1997; Haines et al., 2001; Joyce et al., 2004; Hegde et al., 2007; Huang et al., 2007; Haines et al., 2008). However, limited fatty acid solubility, the high protein concentrations and ionic strengths required for crystallization, and crystal packing effects mean that multiple fatty acid binding may not be observable in crystal structures.

Palmitate binding titrations in $100 \mathrm{mmol} / \mathrm{L}$ phosphate showed two binding sites with no cooperativity. The decrease in the absorbance difference suggested substrate inhibition, but this was not evident in the kinetic titrations which showed Michaelis-Menten behavior. One possibility is that the effect of the binding of the first palmitate molecule would only be observed at low palmitate concentrations. In any case it appeared that the second and third binding sites observed in low ionic strength buffers, with their low $\Delta A_{\max }$ values, were no longer present. This was supported by the hint of a plateau before the rise to higher $\Delta A$ values in myristate binding titrations in $50 \mathrm{mmol} / \mathrm{L}$ Tris, conditions under which kinetic titrations showed deviation from Michaelis-Menten behavior. The effect of ionic strength suggested that ion pairs (salt bridges) in the enzyme structure that maintained specific conformations for additional palmitate molecules to bind, or ion pairs formed between enzyme side chains and the carboxylate group of the substrate, were cleaved at higher ionic strength. Reorganization of ion pairs amongst helices has been proposed to account for the dependence of cooperativity and the heme spin state in the oxidation of 1-pyrenol by CYP107A1 (P450eryF) (Davydov et al., 2004).

The heme distal pocket and the narrow substrate access channel in $\mathrm{P}^{4} \mathrm{~B}_{\mathrm{BM} 3}$ are unlikely to accommodate more than two palmitate molecules, indicating an allosteric rather than space-filling mechanism (Davydov and Halpert, 2008) for at 
least two palmitate binding sites. Numerous examples of sigmoidal kinetics in P450 activity have been described since the first report of such behavior in androstenedione oxidation by rabbit CYP2B enzymes (Ingelman-Sundberg and Johansson, 1980). Atypical kinetics is particularly common for mammalian CYP3A4 and CYP1A2 (Davydov and Halpert, 2008; Denisov et al., 2009), but is also found in bacterial enzymes such as CYP107A1 and CYP102A2/A3. Two substrate binding sites have been established on the distal side of the heme in CYP3A4, but the binding of up to six substrate molecules, together with surface binding sites, open conformations and equilibration between oligomers, have been proposed to model the complex behavior (Davydov and Halpert, 2008). The effect of changes at sites remote from the active site on the product selectivity of $\mathrm{P} 450_{\text {Вм3 }}$ was noted in the oxidation of non-natural substrates by the R47L/Y51F mutant (Carmichael and Wong, 2001), and allosteric effects as well as space-filling mechanisms have been proposed for atypical kinetics in drug oxidation by the R47L/F87A/L188Q mutant (van Vugt-Lussenburg et al., 2006). Since substrate binding is detected by changes in the heme electronic spectrum, a plausible mechanism for the behavior at low ionic strength is that the second and third palmitate molecules bind outside the active site and cause conformational (allosteric) changes that reduce the heme spin state shift and hence $\Delta A_{\max }$. This could occur via altered heme ligation, e.g. movement of the iron that directly impacts on the iron-ligand interactions, or movement of the palmitate molecule within the active site that enables a water molecule to ligate to, or dissociate from, the heme iron. A hydrophobic patch close to the mouth of the substrate access channel has been speculated to be the initial recognition site for fatty acids before the aliphatic chain enters the channel (Hasemann et al., 1995; Li and Poulos, 1997; Haines et al., 2001). If this patch remains accessible after the first fatty acid is bound, it may be an allosteric binding site.

The chain length dependence of the sigmoidal behavior showed that the longer aliphatic chain of palmitate was required for these effects to be manifested. It is worth noting the possibility that the binding of laurate and myristate to the allosteric sites responsible for sigmoidal behavior with palmitate could also change the conformation of the shorter aliphatic side chain of these substrates within the active site without altering the heme spin state and hence would not be detected in the binding or kinetic titrations. In principle, laurate binding at a remote site could therefore alter the conformation of a palmitate molecule bound within the active site. This mechanism offers an alternative explanation for the reported effect of laurate on palmitate oxidation (Rock et al., 2003).

As a result of sigmoidal kinetics, the turnover rate of palmitate at physiological phosphate concentrations is relatively insensitive to substrate concentration below ca. $25 \mu \mathrm{mol} / \mathrm{L}$, while saturation is observed at lower palmitate concentrations such that the turnover rate does not vary with palmitate concentration above ca. $70 \mu \mathrm{mol} / \mathrm{L}$ (Fig. 3). Since phosphate also promotes the first electron transfer, and palmitic acid is an abundant fatty acid in Bacillus membranes, it may be speculated that phosphate concentration plays a role in regulating membrane morphology and fluidity via palmitate metabolism by $\mathrm{P} 450_{\mathrm{BM}}$.

In summary, fatty acid oxidation by $\mathrm{P}^{4} \mathrm{~B}_{\mathrm{BM} 3}$ displays chain length- and ionic strength-dependent homotropic behavior. Palmitate shows sigmoidal kinetics at low ionic strength but Michaelis-Menten behavior at high buffer concentrations. Binding titrations at low ionic strengths indicate at least four fatty acid binding sites in the $\mathrm{P} 40_{\mathrm{BM} 3}$ heme domain that are preserved in the dimeric, full-length enzyme. The presence of multiple binding sites, two or more of which must be outside the active site pocket, shows that allosteric effects are possible in $\mathrm{P}_{450} 0_{\mathrm{BM}}$. Phosphate has been found to promote the first flavin-to-heme electron transfer. These effects may be relevant in the physiological function of this much studied, biotechnologically important enzyme.

\section{MATERIALS AND METHODS}

Dodecanoic (lauric) acid ( $\geqslant 98 \%$ ), tetradecanoic (myristic) acid $(\geqslant 98 \%)$ and hexadecanoic (palmitic) acid ( $\geqslant 99 \%)$ were from Sigma-Aldrich, UK. Stock solutions of these free acids at 1, 10, 50 and $100 \mathrm{mmol} / \mathrm{L}$ concentrations prepared in DMSO were used in all experiments. All buffers were adjusted to $\mathrm{pH} 7.4$ and all experiments were conducted at $30^{\circ} \mathrm{C}$. At $\mathrm{pH} 7.4$ the free acids added as stocks in DMSO would be rapidly and fully deprotonated to form the corresponding conjugate bases.

UV/Vis spectra, substrate binding titrations and NADPH consumption assays were conducted on a Varian Cary 50 or Varian CARY 1E spectrophotometer. Stopped-flow experiments were carried out on an Applied Photophysics SX20 instrument housed inside a Belle Technology glove box operating at $<5 \mathrm{ppm}$ oxygen. Gas chromatographic (GC) analysis of samples was performed on a ThermoFinnigan Trace instrument equipped with an autosampler, using flame-ionization detection and a $15 \mathrm{~m} \mathrm{DB}-1$ column, with helium as carrier gas. The injector was maintained at $200^{\circ} \mathrm{C}$ and the FID at $250^{\circ} \mathrm{C}$.

\section{Enzymes}

Full-length $\mathrm{P}_{450} \mathrm{BM}_{3}$ was produced in E. coli, purified, and quantitated as described previously (Whitehouse et al., 2008). A $30 \mathrm{~mL}$ aliquot of an overnight culture of $E$. coli BL21 (DE3) harboring the pET28$\mathrm{P}^{4} 50_{\mathrm{BM} 3}$ plasmid was inoculated into $1 \mathrm{~L}$ of $\mathrm{LB}$ medium containing $0.4 \%(\mathrm{~V} / \mathrm{V})$ glycerol and $30 \mathrm{mg} / \mathrm{L}$ kanamycin and grown at $37^{\circ} \mathrm{C}$ at $180 \mathrm{rpm}$ until $\mathrm{OD}_{600}>1$. The incubator temperature was lowered to $30^{\circ} \mathrm{C}$ and protein expression induced by adding isopropyl- $\beta-\mathrm{D}$ thiogalactopyranoside (IPTG) to $0.4 \mathrm{mmol} / \mathrm{L}$. After a further $12 \mathrm{~h}$ of growth at $30^{\circ} \mathrm{C}$, cells were harvested by centrifugation. The redbrown pellet from each $1 \mathrm{~L}$ growth was re-suspended in $25 \mathrm{~mL}$ $40 \mathrm{mmol} / \mathrm{L}$ potassium phosphate, $\mathrm{pH} 7.4,1 \mathrm{mmol} / \mathrm{L}$ in dithiothreitol (Buffer P). The cells were lysed by sonication, and cell debris was cleared by centrifugation at $37,500 \mathrm{~g}$ for $30 \mathrm{~min}$ at $4^{\circ} \mathrm{C}$. The 
supernatant was loaded onto a DEAE fast flow Sepharose column ( $200 \mathrm{~mm} \times 50 \mathrm{~mm}$, GE Healthcare) pre-equilibrated with Buffer $P$ from which the protein was eluted using a linear gradient of $80-400 \mathrm{mmol} / \mathrm{L}$ ammonium sulfate in Buffer P. The red brown P450 fractions were collected and concentrated by ultrafiltration, desalted using a Sephadex G-25 column pre-equilibrated with Buffer $P$, and reconcentrated by ultrafiltration. The solution was centrifuged at $9250 \mathrm{~g}$ for $5 \mathrm{~min}$ at $4^{\circ} \mathrm{C}$ and filter sterilized. FPLC anion-exchange purification was carried out on a Source-Q column $(120 \mathrm{~mm} \times 26 \mathrm{~mm}$, GE Healthcare) using a linear gradient of $0-30 \% 15 \times$ Buffer $P$. Fractions with $A_{418} / A_{280}>0.35$ were collected, concentrated by ultrafiltration and filter sterilized before being stored at $-20^{\circ} \mathrm{C}$ in $50 \%(\mathrm{~V} / \mathrm{V})$ glycerol. Glycerol and salts were removed from proteins immediately prior to experiments using a $5 \mathrm{~mL}$ PD-10 column (GE Healthcare) pre-equilibrated with the appropriate buffer.

The heme domain of $\mathrm{P}^{4} 50_{\mathrm{BM} 3}$ was produced in E. coli, purified, and quantitated as described previously (Whitehouse et al., 2009). The pET28-BMP plasmid was transformed into E. coli BL21 (DE3). Growth and expression were as for full length $\mathrm{P}_{450} \mathrm{BM}_{\mathrm{BM}}$. Cell pellets were resuspended in $50 \mathrm{mmol} / \mathrm{L}$ Tris, $\mathrm{pH} \mathrm{7.4,} \mathrm{a} \mathrm{linear} \mathrm{gradient} \mathrm{of}$ $100-300 \mathrm{mmol} / \mathrm{L} \mathrm{KCl}$ in $50 \mathrm{mmol} / \mathrm{L}$ Tris, $\mathrm{pH} 7.4$ was employed for the DEAE Sepharose fast-flow column and a linear gradient of $50-200 \mathrm{mmol} / \mathrm{L} \mathrm{KCl}$ in $50 \mathrm{mmol} / \mathrm{L}$ Tris, $\mathrm{pH} 7.4$ on the Source-Q column. Storage and glycerol/salt removal were as for the full-length protein.

\section{The heme spin state}

Spin state spectra were acquired on a Cary $1 \mathrm{E}$ dual beam spectrophotometer. The sample cuvette contained $3 \mu \mathrm{mol} / \mathrm{L}$ $\mathrm{P} 40_{\mathrm{BM} 3}$ in buffer, giving a $418 \mathrm{~nm}$ absorbance of ca. 0.45 . The reference cuvette contained buffer only. The substrate-free spectrum was recorded. An aliquot of the substrate $(50 \mathrm{mmol} / \mathrm{L}$ in DMSO) was added to the sample cuvette and the same volume to the reference cuvette and the spectrum was recorded. This process was repeated until the high spin content was maximized. To test the effect of other buffers and ions, $100 \mu \mathrm{L}$ of $1 \mathrm{~mol} / \mathrm{L}$ Tris, phosphate or $\mathrm{KCl}$ was added to the substrate-saturated enzyme. This was repeated at additive concentrations up to $400 \mathrm{mmol} / \mathrm{L}$.

\section{Substrate binding titrations}

Binding titrations were performed on a Cary 1E spectrophotometer. Eluted and quantitated full-length $\mathrm{P} 450_{\mathrm{BM}}$ or its heme domain was diluted in the appropriate buffer. $1000 \mu \mathrm{L}$ of this solution was placed in each of the reference and sample cuvette. Substrate was added as a $1 \mathrm{mmol} / \mathrm{L}$ or $10 \mathrm{mmol} / \mathrm{L}$ solution in DMSO to the sample cuvette using a Hamilton syringe, while DMSO was added to the reference cuvette. The maximum final concentration of DMSO in the protein solution was $<2 \%(v / v)$. The spectra were recorded between 350 and $500 \mathrm{~nm}$, and the absorbance was set to zero after each substrate addition before initiating the spectral scan. The peak-to-trough difference between the $388 \mathrm{~nm}$ and $420 \mathrm{~nm}$ peaks in the difference spectra thus obtained was scaled for dilution and fitted against substrate concentration using Origin Pro 8 software (Origin Labs).

\section{NADPH consumption assays}

The total reaction volume was $1000 \mu \mathrm{L}$. The final concentration of
$\mathrm{P} 450_{\mathrm{BM}}$ in activity assays was $0.1 \mu \mathrm{mol} / \mathrm{L}$. The following steps were taken to minimize monomer formation (Neeli et al., 2005; Kitazume et al., 2007). For activity assays in $10 \mathrm{mmol} / \mathrm{L}$ and $25 \mathrm{mmol} / \mathrm{L}$ phosphate, the enzyme was eluted from the PD-10 column with $50 \mathrm{mmol} / \mathrm{L}$ phosphate to maintain it in the dimeric form. The substrate was added first as a $50 \mathrm{mmol} / \mathrm{L}, 10 \mathrm{mmol} / \mathrm{L}$ or $1 \mathrm{mmol} / \mathrm{L}$ solution in DMSO as appropriate, to the incubation buffer. Pure DMSO was added as necessary to achieve a final concentration of $2 \%(\mathrm{~V} / \mathrm{V})$ prior to substrate addition in order to improve substrate solubility. The mixture was incubated at $30^{\circ} \mathrm{C}$ for $1 \mathrm{~min}$ in the cuvette. The enzyme (20-25 $\mu \mathrm{L}$ of $\mathrm{a}>5 \mu \mathrm{mol} / \mathrm{L}$ stock solution kept on ice) was then added to the substrate solution $(900-940 \mu \mathrm{L})$ in the cuvette. NADPH was added immediately as a $20 \mathrm{mg} / \mathrm{mL}$ stock in the appropriate buffer to $A_{340} \approx 1(160 \mu \mathrm{mol} / \mathrm{L})$. The cuvette was quickly inverted a few times and then the absorbance at $340 \mathrm{~nm}$ recorded over time. The time delay between enzyme dilution and the start of kinetic measurement was less than $60 \mathrm{~s}$ in all experiments. The initial gradient was measured, and the NADPH consumption rate calculated using $\varepsilon_{340}=$ $6.22(\mathrm{mmol} / \mathrm{L})^{-1} \cdot \mathrm{cm}^{-1}$.

\section{Product analysis}

Palmitic acid is soluble to $200 \mu \mathrm{mol} / \mathrm{L}$ in buffer containing $2 \%(\mathrm{v} / \mathrm{v})$ DMSO. At this substrate concentration $0.2 \mu \mathrm{mol} / \mathrm{L}$ protein in Tris buffer can be saturated and $0.1 \mu \mathrm{mol} / \mathrm{L}$ protein in phosphate, and these were the concentrations used. Palmitic acid and lauric acid solutions were also prepared for standardization. A $990 \mu \mathrm{L}$ aliquot from each NADPH turnover reaction was transferred to a microcentrifuge tube, and $10 \mu \mathrm{L}$ of $25 \mathrm{mmol} / \mathrm{L}$ decanoic acid in ethanol added, then $2.5 \mu \mathrm{L}$ of concentrated $\mathrm{HCl}$ and finally $400 \mu \mathrm{L}$ of ethyl acetate. After centrifuging for $5 \mathrm{~min}$ at $14,500 \mathrm{~g}$, the ethyl acetate layer was removed and dried over $\mathrm{MgSO}_{4}$. The solution was centrifuged and the ethyl acetate removed and retained. $500 \mu \mathrm{L}$ of fresh ethyl acetate was added to the remaining $\mathrm{MgSO}_{4}$ and centrifuged before removing and combining with the previously removed ethyl acetate. The solution was evaporated to dryness under a stream of nitrogen, and the resulting residue dissolved in $200 \mu \mathrm{L}$ of acetonitrile. N,O-bis(trimethylsilyl)trifluoroacetamide and trimethylchlorosilane (BSTFA/ TMCS, 99:1) was added $(25 \mu \mathrm{L})$ and the solution left at $50^{\circ} \mathrm{C}$ for $3 \mathrm{~h}$. The samples were subjected directly to $\mathrm{GC}$ analysis. The oven temperature was held at $100^{\circ} \mathrm{C}$ for $1 \mathrm{~min}$ and then raised at $15^{\circ} \mathrm{C}$ per minute to $220^{\circ} \mathrm{C}$. The retention times and, in brackets, the mean percentage of the trimethylsilyl derivatives were: 11-hydroxylauric acid $9.17 \mathrm{~min}$ (32\%), 10-hydroxylauric acid $9.07 \mathrm{~min}$ (29\%), 9hydroxylauric acid $8.90 \mathrm{~min}(39 \%)$ for lauric acid oxidation, and 15hydroxypalmitic acid 12.20 min (31\%), 14-hydroxypalmitic acid $12.02 \mathrm{~min}$ (48\%), 13-hydroxypalmitic acid $11.60 \mathrm{~min}(21 \%)$ for palmitic acid oxidation. The product percentages under various buffer conditions did not deviate by more than $2 \%$ from the mean values.

\section{Stopped-flow studies}

Eluted and quantified $\mathrm{P} 450_{\mathrm{BM} 3}$ was diluted to $1 \mu \mathrm{mol} / \mathrm{L}$. Substrate was added to the limit of solubility in buffer with $2 \%(v / v)$ DMSO (lauric aid $1000 \mu \mathrm{mol} / \mathrm{L}$, myristic acid $250 \mu \mathrm{mol} / \mathrm{L}$, and palmitic acid $200 \mu \mathrm{mol} / \mathrm{L})$. A $200 \mu \mathrm{mol} / \mathrm{L}$ NADPH solution was prepared in buffer with $2 \%(v / v)$ DMSO. Both solutions were sealed in $15 \mathrm{~mL}$ tubes and $\mathrm{CO}$ was bubbled by syringe slowly for $5 \mathrm{~min}$ in the solution and $5 \mathrm{~min}$ vigorously above the solution. The resulting CO-saturated and 
oxygen-free solutions were transferred inside a glove box. The stopped-flow cell, maintained at $(30 \pm 0.1)^{\circ} \mathrm{C}$, was washed with water, then twice with buffer before a baseline was determined. The protein and NADPH solutions were transferred to $5 \mathrm{~mL}$ syringes and prepared for injection. The instrument was set to record the absorbance at $450 \mathrm{~nm}$ with 4000 data points over $250 \mathrm{~ms}$. The data were analyzed using Pro-Data Viewer SX supplied with the instrument. The data for lauric acid in 50,150 , or $250 \mathrm{mmol} / \mathrm{L}$ Tris,

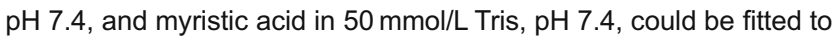
single exponentials. For palmitic acid in Tris and phosphate buffers, and lauric and myristic acid in phosphate buffer, double exponentials with a slow phase $\left(31-39 \mathrm{~s}^{-1}\right)$ were required to fit the data (Girvan et al., 2011; Whitehouse et al., 2011).

\section{ACKNOWLEDGEMENTS}

This work was supported by grants from the Natural Sciences and Engineering Research Council (NSERC), Canada, and the Rhodes Trust (JY), and the Higher Educational Funding Council for England.

Supplementary material is available in the online version of this article at http://dx.doi.org/10.1007/s13238-011-1082-6 and is accessible for authorized users.

\section{REFERENCES}

Baas, B.J., Denisov, I.G., and Sligar, S.G. (2004). Homotropic cooperativity of monomeric cytochrome P450 3A4 in a nanoscale native bilayer environment. Arch Biochem Biophys 430, 218-228.

Bell, S.G., Dale, A., Rees, N.H., and Wong, L.L. (2010a). A cytochrome P450 class I electron transfer system from Novosphingobium aromaticivorans. Appl Microbiol Biotechnol 86, 163-175.

Bell, S.G., Hoskins, N., Whitehouse, C.J.C., and Wong, L.-L. (2007). Design and Engineering of Cytochrome P450 Systems. Metal lons Life Sci 3, 437-476.

Bell, S.G., Tan, A.B., Johnson, E.O., and Wong, L.L. (2010b). Selective oxidative demethylation of veratric acid to vanillic acid by CYP199A4 from Rhodopseudomonas palustris HaA2. Mol Biosyst 6, 206-214.

Bell, S.G., and Wong, L.L. (2007). P450 enzymes from the bacterium Novosphingobium aromaticivorans. Biochem Biophys Res Commun 360, 666-672.

Bell, S.G., Xu, F., Johnson, E.O., Forward, I.M., Bartlam, M., Rao, Z., and Wong, L.L. (2010c). Protein recognition in ferredoxin-P450 electron transfer in the class I CYP199A2 system from Rhodopseudomonas palustris. J Biol Inorg Chem 15, 315-328.

Brewer, C.B., and Peterson, J.A. (1988). Single turnover kinetics of the reaction between oxycytochrome P-450cam and reduced putidaredoxin. J Biol Chem 263, 791-798.

Budde, M., Maurer, S.C., Schmid, R.D., and Urlacher, V.B. (2004). Cloning, expression and characterisation of CYP102A2, a selfsufficient P450 monooxygenase from Bacillus subtilis. Appl Microbiol Biotechnol 66, 180-186.

Carmichael, A.B., and Wong, L.L. (2001). Protein engineering of Bacillus megaterium CYP102. The oxidation of polycyclic aromatic hydrocarbons. Eur J Biochem 268, 3117-3125.

Chowdhary, P.K., Alemseghed, M., and Haines, D.C. (2007). Cloning, expression and characterization of a fast self-sufficient P450:
CYP102A5 from Bacillus cereus. Arch Biochem Biophys 468, 32-43.

Cryle, M.J., Espinoza, R.D., Smith, S.J., Matovic, N.J., and De Voss, J.J. (2006). Are branched chain fatty acids the natural substrates for P450(BM3)? Chem Commun 2353-2355.

Davydov, D.R., Botchkareva, A.E., Kumar, S., He, Y.Q., and Halpert, J.R. (2004). An electrostatically driven conformational transition is involved in the mechanisms of substrate binding and cooperativity in cytochrome P450eryF. Biochemistry 43, 6475-6485.

Davydov, D.R., and Halpert, J.R. (2008). Allosteric P450 mechanisms: multiple binding sites, multiple conformers or both? Expert Opin Drug Metab Toxicol 4, 1523-1535.

Denisov, I.G., Baas, B.J., Grinkova, Y.V., and Sligar, S.G. (2007). Cooperativity in cytochrome P450 3A4: linkages in substrate binding, spin state, uncoupling, and product formation. J Biol Chem 282, 7066-7076.

Denisov, I.G., Frank, D.J., and Sligar, S.G. (2009). Cooperative properties of cytochromes P450. Pharmacol Ther 124, 151-167.

Dietrich, M., Eiben, S., Asta, C., Do, T.A., Pleiss, J., and Urlacher, V.B. (2008). Cloning, expression and characterisation of CYP102A7, a self-sufficient P450 monooxygenase from Bacillus licheniformis. Appl Microbiol Biotechnol 79, 931-940.

Girvan, H.M., Dunford, A.J., Neeli, R., Ekanem, I.S., Waltham, T.N., Joyce, M.G., Leys, D., Curtis, R.A., Williams, P., Fisher, K., et al. (2011). Flavocytochrome P450 BM3 mutant W1046A is a NADHdependent fatty acid hydroxylase: implications for the mechanism of electron transfer in the P450 BM3 dimer. Arch Biochem Biophys $507,75-85$.

Guengerich, F.P. (2001). Common and uncommon cytochrome P450 reactions related to metabolism and chemical toxicity. Chem Res Toxicol 14, 611-650.

Gustafsson, M.C., Roitel, O., Marshall, K.R., Noble, M.A., Chapman, S.K., Pessegueiro, A., Fulco, A.J., Cheesman, M.R., von Wachenfeldt, C., and Munro, A.W. (2004). Expression, purification, and characterization of Bacillus subtilis cytochromes P450 CYP102A2 and CYP102A3: flavocytochrome homologues of P450 BM3 from Bacillus megaterium. Biochemistry 43, 5474-5487.

Haines, D.C., Chen, B., Tomchick, D.R., Bondlela, M., Hegde, A., Machius, M., and Peterson, J.A. (2008). Crystal structure of inhibitor-bound P450BM-3 reveals open conformation of substrate access channel. Biochemistry 47, 3662-3670.

Haines, D.C., Sevrioukova, I.F., and Peterson, J.A. (2000). The FMNbinding domain of cytochrome P450BM-3: resolution, reconstitution, and flavin analogue substitution. Biochemistry 39 , 9419-9429.

Haines, D.C., Tomchick, D.R., Machius, M., and Peterson, J.A. (2001). Pivotal role of water in the mechanism of P450BM-3. Biochemistry 40, 13456-13465.

Hasemann, C.A., Kurumbail, R.G., Boddupalli, S.S., Peterson, J.A., and Deisenhofer, J. (1995). Structure and function of cytochromes P450: a comparative analysis of three crystal structures. Structure 3, 41-62.

Hegde, A., Haines, D.C., Bondlela, M., Chen, B., Schaffer, N., Tomchick, D.R., Machius, M., Nguyen, H., Chowdhary, P.K., Stewart, L., et al. (2007). Interactions of substrates at the surface of $\mathrm{P} 450$ s can greatly enhance substrate potency. Biochemistry 46, 14010-14017.

Huang, W.C., Westlake, A.C., Maréchal, J.D., Joyce, M.G., Moody, P. 
C., and Roberts, G.C. (2007). Filling a hole in cytochrome P450 BM3 improves substrate binding and catalytic efficiency. J Mol Biol 373, 633-651.

Ingelman-Sundberg, M., and Johansson, I. (1980). Catalytic properties of purified forms of rabbit liver microsomal cytochrome P-450 in reconstituted phospholipid vesicles. Biochemistry 19, 4004-4011.

Jovanovic, T., Farid, R., Friesner, R.A., and McDermott, A.E. (2005). Thermal equilibrium of high- and low-spin forms of cytochrome P450 BM-3: repositioning of the substrate? J Am Chem Soc 127, 13548-13552.

Joyce, M.G., Girvan, H.M., Munro, A.W., and Leys, D. (2004). A single mutation in cytochrome P450 BM3 induces the conformational rearrangement seen upon substrate binding in the wild-type enzyme. J Biol Chem 279, 23287-23293.

Kitazume, T., Haines, D.C., Estabrook, R.W., Chen, B., and Peterson, J.A. (2007). Obligatory intermolecular electron-transfer from $F A D$ to FMN in dimeric P450BM-3. Biochemistry 46, 11892-11901.

Lentz, O., Urlacher, V., and Schmid, R.D. (2004). Substrate specificity of native and mutated cytochrome P450 (CYP102A3) from Bacillus subtilis. J Biotechnol 108, 41-49.

Li, H., and Poulos, T.L. (1997). The structure of the cytochrome p450BM-3 haem domain complexed with the fatty acid substrate, palmitoleic acid. Nat Struct Biol 4, 140-146.

Li, Q.S., Ogawa, J., Schmid, R.D., and Shimizu, S. (2005). Indole hydroxylation by bacterial cytochrome P450BM-3 and modulation of activity by cumene hydroperoxide. Biosci Biotechnol Biochem 69, 293-300.

Malik, W.U., and Jain, A.K. (1967). Electrometric determination of critical micelle concentrations of soap solutions. J Electroanal Chem 14, 37-41.

Maurer, S.C., Kuhnel, K., Kaysser, L.A., Eiben, S., Schmid, R.D., and Urlacher, V.B. (2005). Catalytic hydroxylation in biphasic systems using CYP102A1 mutants. Adv Synth Catal 347, 1090-1098.

Maves, S.A., Yeom, H., McLean, M.A., and Sligar, S.G. (1997). Decreased substrate affinity upon alteration of the substratedocking region in cytochrome P450BM-3. FEBS Lett 414, 213-218.

Mizushima, S., Ishida, M., and Kitahara, K. (1966). Chemical composition of the protoplast membrane of Bacillus megaterium. J Biochem 59, 374-381.

Modi, S., Primrose, W.U., Lian, L.Y., and Roberts, G.C. (1995). Effect of replacement of ferriprotoporphyrin IX in the haem domain of cytochrome P-450 BM-3 on substrate binding and catalytic activity. Biochem J 310, 939-943.

Munro, A.W., Daff, S., Coggins, J.R., Lindsay, J.G., and Chapman, S. K. (1996). Probing electron transfer in flavocytochrome P-450 BM3 and its component domains. Eur J Biochem 239, 403-409.

Narhi, L.O., and Fulco, A.J. (1986). Characterization of a catalytically self-sufficient 119,000-dalton cytochrome P-450 monooxygenase induced by barbiturates in Bacillus megaterium. J Biol Chem 261, 7160-7169.

Narhi, L.O., and Fulco, A.J. (1987). Identification and characterization of two functional domains in cytochrome P-450BM-3, a catalytically self-sufficient monooxygenase induced by barbiturates in Bacillus megaterium. J Biol Chem 262, 6683-6690.

Neeli, R., Girvan, H.M., Lawrence, A., Warren, M.J., Leys, D., Scrutton, N.S., and Munro, A.W. (2005). The dimeric form of flavocytochrome P450 BM3 is catalytically functional as a fatty acid hydroxylase. FEBS Lett 579, 5582-5588.

Noble, M.A., Miles, C.S., Chapman, S.K., Lysek, D.A., MacKay, A.C., Reid, G.A., Hanzlik, R.P., and Munro, A.W. (1999). Roles of key active-site residues in flavocytochrome P450 BM3. Biochem J 339, 371-379.

Ost, T.W., Clark, J., Mowat, C.G., Miles, C.S., Walkinshaw, M.D., Reid, G.A., Chapman, S.K., and Daff, S. (2003). Oxygen activation and electron transfer in flavocytochrome P450 BM3. J Am Chem Soc 125, 15010-15020.

Roberts, A.G., Campbell, A.P., and Atkins, W.M. (2005). The thermodynamic landscape of testosterone binding to cytochrome P450 3A4: ligand binding and spin state equilibria. Biochemistry 44, 1353-1366.

Rock, D.A., Perkins, B.N.S., Wahlstrom, J., and Jones, J.P. (2003). A method for determining two substrates binding in the same active site of cytochrome P450BM3: an explanation of high energy omega product formation. Arch Biochem Biophys 416, 9-16.

Urlacher, V.B., and Eiben, S. (2006). Cytochrome P450 monooxygenases: perspectives for synthetic application. Trends Biotechnol 24, 324-330.

van Vugt-Lussenburg, B.M., Damsten, M.C., Maasdijk, D.M., Vermeulen, N.P., and Commandeur, J.N. (2006). Heterotropic and homotropic cooperativity by a drug-metabolising mutant of cytochrome P450 BM3. Biochem Biophys Res Commun 346, 810-818.

Whitehouse, C.J., Bell, S.G., Tufton, H.G., Kenny, R.J., Ogilvie, L.C., and Wong, L.L. (2008). Evolved CYP102A1 (P450BM3) variants oxidise a range of non-natural substrates and offer new selectivity options. Chem Commun 966-968.

Whitehouse, C.J., Bell, S.G., Yang, W., Yorke, J.A., Blanford, C.F., Strong, A.J., Morse, E.J., Bartlam, M., Rao, Z., and Wong, L.L. (2009). A highly active single-mutation variant of P450BM3 (CYP102A1). Chembiochem 10, 1654-1656.

Whitehouse, C.J., Yang, W., Yorke, J.A., Rowlatt, B.C., Strong, A.J., Blanford, C.F., Bell, S.G., Bartlam, M., Wong, L.L., and Rao, Z. (2010). Structural basis for the properties of two single-site proline mutants of CYP102A1 (P450BM3). Chembiochem 11, 2549-2556.

Whitehouse, C.J.C., Yang, W., Yorke, J.A., Tufton, H.G., Ogilvie, L.C. I., Bell, S.G., Zhou, W., Bartlam, M., Rao, Z., and Wong, L.L. (2011). Structure, electronic properties and catalytic behaviour of an activity-enhancing CYP102A1 (P450BM3) variant. Dalton Trans May 20. [Epub ahead of print] DOI: 10.1039/C1DT10098J

Yang, W., Bell, S.G., Wang, H., Zhou, W., Hoskins, N., Dale, A., Bartlam, M., Wong, L.L., and Rao, Z. (2010). Molecular characterization of a class I P450 electron transfer system from Novosphingobium aromaticivorans DSM12444. J Biol Chem 285, 27372-27384.

Yeom, H.Y., and Sligar, S.G. (1997). Oxygen activation by cytochrome P450BM-3: effects of mutating an active site acidic residue. Arch Biochem Biophys 337, 209-216. 